\title{
Technology Deployment Annual Report 2013 December
}

January 2014

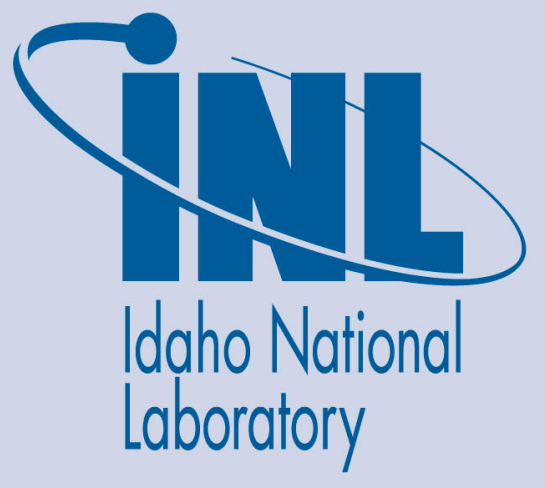

The INL is a U.S. Department of Energy National Laboratory operated by Battelle Energy Alliance 
INL/EXT-14-31024

\title{
Technology Deployment Annual Report 2013 December
}

January 2014

\author{
Idaho National Laboratory \\ Idaho Falls, Idaho 83415
}

http://www.inl.gov

Prepared for the

U.S. Department of Energy

Office of Nuclear Energy

Under DOE Idaho Operations Office

Contract DE-AC07-05ID14517 


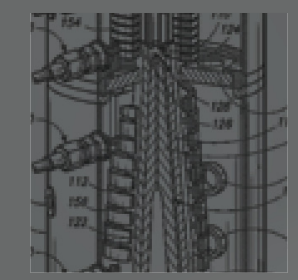

\section{Technology Deployment}

$\square$

Annual Report 2013

December
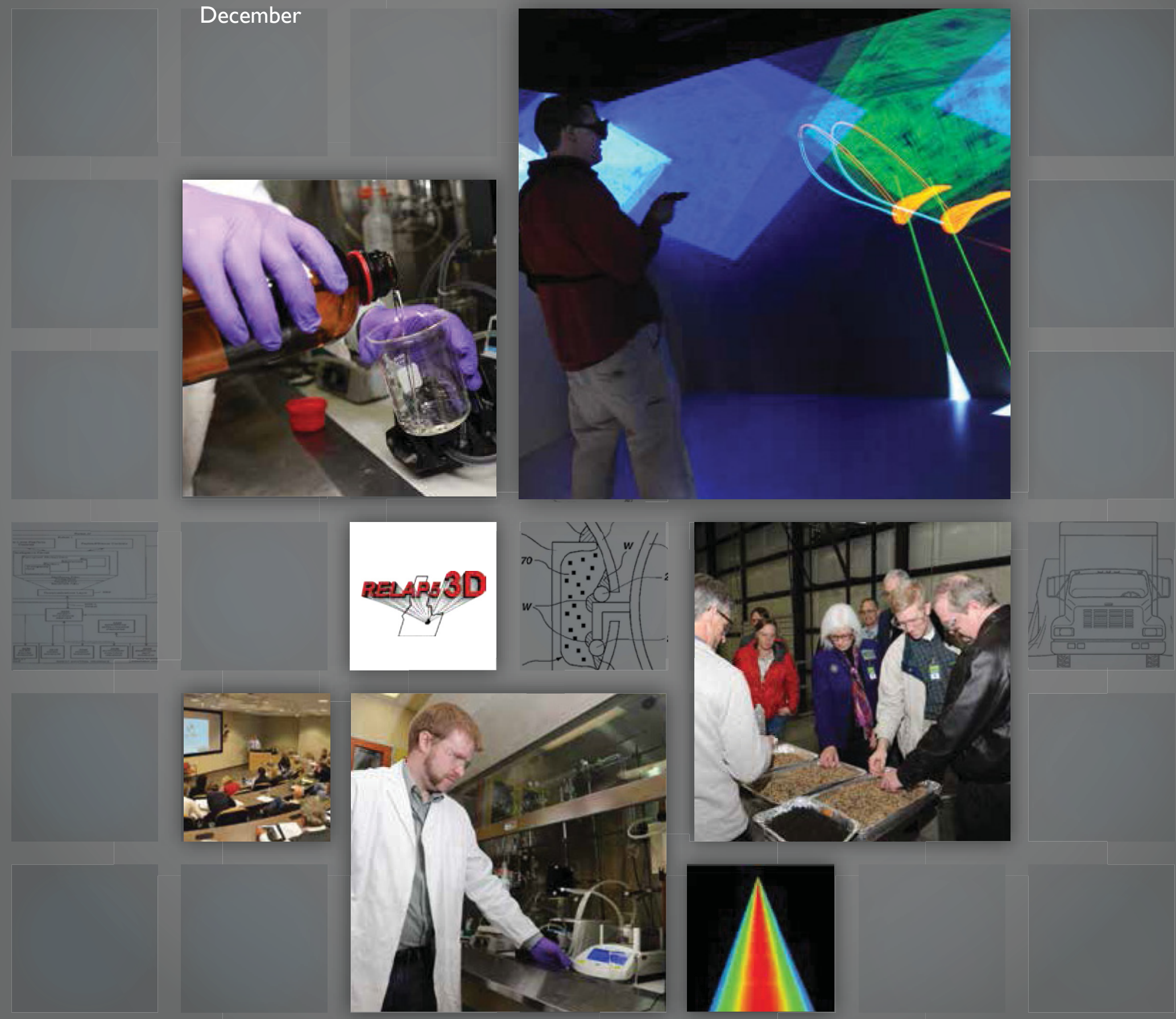

Idaho National Laboratory

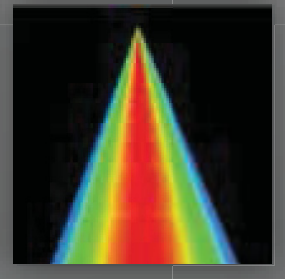




\section{Abstract}

Idaho National Laboratory (INL) is a Department of Energy (DOE) multi-program national laboratory that conducts research and development in all DOE mission areas. Like all other federal laboratories, INL has a statutory technology transfer mission to make its capabilities and technologies available to all federal agencies, to state and local governments, and to universities and industry. To fulfill this mission, INL encourages its scientific, engineering, and technical staff to disclose new inventions and creations to ensure the resulting intellectual property is captured, protected, and made available to others who might benefit from it.

As part of the mission, intellectual property is licensed to industrial partners for commercialization, creating jobs and delivering the benefits of federally funded technology to consumers. In other cases, unique capabilities are made available to other federal agencies or to regional small businesses to solve specific technical challenges. INL employees also work cooperatively with researchers and technical staff from the university and industrial sectors to further develop emerging technologies. In a multinational global economy, INL is contributing to the development of the next generation of engineers and scientists by licensing software to educational instiutitons throughout the world.

This report is a catalog of selected INL technology transfer and commercialization transactions during this past year. The size and diversity of INL technical resources, coupled with the large number of relationships with other organizations, virtually ensures that a report of this nature will fail to capture all interactions. Recognizing this limitation, this report focuses on transactions that are specifically authorized by technology transfer legislation (and corresponding contractual provisions) or involve the transfer of legal rights to technology to other parties.

This report was compiled from primary records, which were readily available to the INL's Office of Technology Deployment. However, the accomplishments cataloged in the report reflect the achievements and creativity of the researchers, technicians, support staff, and operators of the INL workforce.

\section{Disclaimer}

This information was prepared as an account of work sponsored by an agency of the U.S. Government. Neither the U.S. Government nor any agency thereof, nor any of their employees, makes any warranty, expressed or implied, or assumes any legal liability or responsibility for the accuracy, completeness, or usefulness, of any information, apparatus, product, or process disclosed, or represents that its use would not infringe privately owned rights. References herein to any specific commercial product, process, or service by trade name, trade mark, manufacturer, or otherwise, does not necessarily constitute or imply its endorsement, recommendation, or favoring by the U.S. Government or any agency thereof. The views and opinions of authors expressed herein do not necessarily state or reflect those of the U.S. Government or any agency thereof. 


\section{Contents}

From the Laboratory Director .................................................. 2

From the Technology Deployment Director ..................................... 3

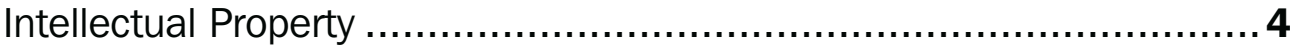

Granted Copyrights.............................................................. 13

License Highlights ............................................................ 14

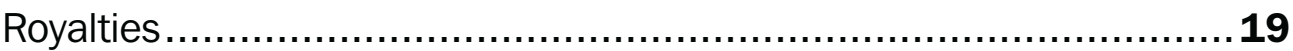

Cooperative Research and Development Agreement Highlights ..........20

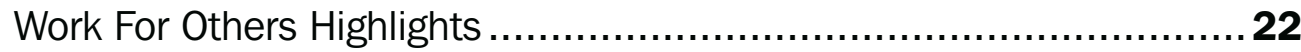

Technology-Based Economic Development Highlights...................... 26

Switchable Polarity Solvent Forward Osmosis wins awards .................30 


\section{From the Laboratory Director}

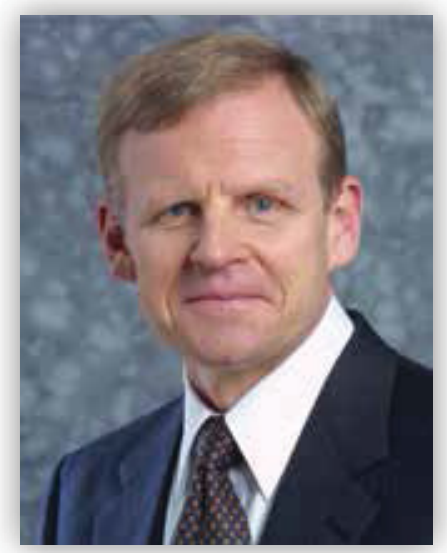

Fiscal Year 2013 has been another important year for the Idaho National Laboratory (INL). New capabilities, such as the Energy Systems Laboratory, have been added in pursuit of our vision for the nation's nuclear energy research and multi-mission laboratory.

INL's Technology Deployment (TD) department has made important contributions that support our Nation's energy security and economy. In particular, TD has continued to refine business processes, accelerated software

licensing, and nurtured expanding relationships through nearly 100 new deployment agreements during FY2013. INL has experienced a rapid rise in the number of copyright assertions and a growing number of software licensing agreements. INL developed software offers solutions to increasingly complex science and engineering challenges.

During the past nine years, INL has signed more than 655 new technology license agreements. TD continues to do good work in negotiating and leveraging INL innovation through Collaborative Research and Development Agreements (CRADAs) and Work for Other (WFO) agreements. INL will continue its efforts to expand collaboration with government and industry organizations.

A good example of the work being done in industry is INL's work with Bill Gates of TerraPower, LLC, who visited INL in October 2013 This year INL signed two CRADAs to help the company advance their traveling wave reactor design. More agreements for research and development are expected in the future, expanding the collaboration between TerraPower and INL.

INL's reputation in the nuclear industry continues to grow with more than 70 active licenses for RELAP5-3D, the world's premier safety, modeling and simulation code. In FY2013, 35 new licenses were executed and 15 more were modified. The International RELAP Users Group held its annual conference in Idaho Falls, augmenting it with a well-attended training seminar.

In addition to TerraPower, TD supported other key agreements in industry, including some well-known companies such as Duke Energy, Chevron, GE, Schneider Electric, Hitachi, Emery Energy Company, Ontario Power Generation, NuScale Power and more.

Royalties earned during the year from INL's licensed intellectual property exceeded \$1.55 million. With 39 new patents issued during FY2013, licensing of these technologies continues to advance the commercialization of INL research.

Researchers gained more international recognition for INL by earning our 48th R\&D 100 award since 1986. That technology, Switchable

\section{“The Technology Deployment (TD) department has made important contributions in support of our vision of significantly impacting our Nation's energy security and economic development through strategic deployment of our capabilities and technologies."}

\section{John J. Grossenbacher Director, Idaho National Laboratory}

Polarity Solvent Forward Osmosis (SPS FO), may someday help clean industrial waste water for reuse. SPS FO may also help with other industrial water cleansing situations and shows promise for desalination. SPS FO also earned the Federal Laboratory Consortium - Far West award for outstanding technology development and the regional Idaho Innovation Award in the same category.

INL continues to encourage the entrepreneurial ecosystem in the region to build, connect and inspire economic activity. Working with local universities and regional economic development associations, INL has sponsored workshops, industry forums, and entrepreneurial symposia to stimulate economic development. INL co-sponsored the BIG (Business+Innovation+Growth) Competition in southeastern Idaho, where local entrepreneurs were able to share innovative ideas, and TechLaunch 10.0 in Boise, which began in 2004. After ten years, 55 of 72 companies participating in TechLaunch are still in business today, attracting more than $\$ 40$ million in $\mathrm{R} \& \mathrm{D}$ and investment capital.

Our researchers generated 32 Invention Disclosure Records and were issued 39 patents during the year, raising the nine year total to nearly 361 issued patents. Since 2005, INL has filed nearly 396 patent applications.

Please take a few minutes to read this summary, which offers details about INL deploying technology, conducting research and executing work. INL delivered an excellent return to America's taxpayer for their investment in deploying Idaho National Laboratory technologies developed by its talented, award-winning researchers.

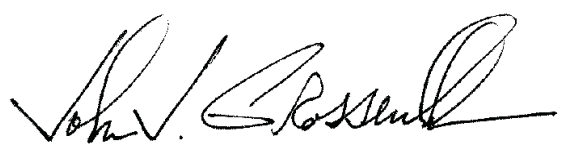

John Grossenbacher

Director, Idaho National Laboratory 


\section{From the Technology Deployment Director}

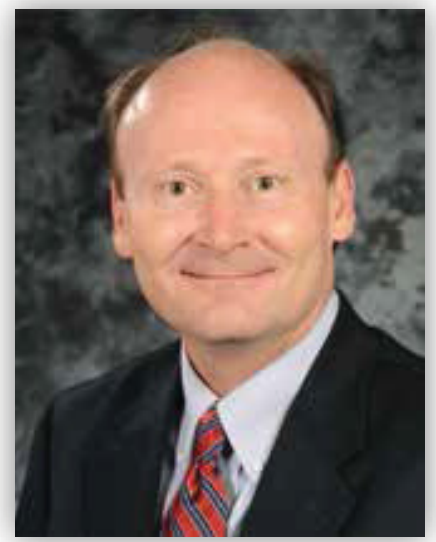

FY2013 presented new challenges and opportunities for deploying INL technologies. In a world that is increasingly reliant on digital systems, INL continues to contribute to the Nation's energy economy by developing robust software tools and industrial control system software that keeps America's infrastructure safe and operating.

This year the Technology Deployment (TD) department has focused on deploying a number of these new software tools and safeguards. The interest in RELAP5-3D has continued to grow and 35 new licenses have made this invaluable safety, design and training code available to more in the nuclear industry. But other new software has emerged quickly and in answer to divergent needs.

PHISICS - Parallel and Highly Innovative Simulation for INL Code System - provides a modern analysis tool for reactor physics investigation with six non-exclusive licenses signed this year. Nuclear research organizations around the world have shown interest and are using this important tool that maximizes accuracy for available computational resources.

MOOSE - Multiphysics Object Oriented Simulation Environment - software offers a framework for complex engineering analysis. INL researchers saw a need for this framework and petitioned for Laboratory Directed Research and Development funds to develop the framework. Great interest has been show in MOOSE with 19 multi-year licenses signed this year.

Sophia - An industrial control system and computer network fingerprinting tool, completed its beta testing with technical input from 41 beta licensees and input on commercial software application potential from 7 evaluation licensees. These groups included U.S. universities and companies engaged in electricity generation, transmission and distribution. U.S. government agencies have also shown significant interest in Sophia with 7 government use licenses executed during the year.

In parallel with the increased interest for software licensing at INL we've also seen a commensurate increase in copyright assertions for potentially licensable software applications. In fact, INL received permission to assert copyright for 21 newly developed software products. Seventeen of these had National and Homeland Security application. We anticipate this copyrighted software having an impact in the near future as new applications are licensed for use in the commercial world.

Also during FY2013, TD continued working to develop business relationships that will leverage and deploy INL's capabilities. Efforts during the year helped established 37 relationships of strategic importance with organizations such as TerraPower, Ontario Power, Electric Power Research Institute (EPRI), Honeywell, Duke Energy, AMETEK, GE and others.

This annual report endeavors to provide a detailed summary of key efforts to deploy technologies during FY2013. Some statistics demonstrate

\section{"Our goal is to leverage renewed capabilities at INL to create more advances, innovations and discoveries."}

\section{Steven T. McMaster, Director, Technology Deployment}

the focus and strength of TD's emphasis on business development and the impact of INL's enterprise-wide efforts.

During FY2013, U.S. businesses marketed more than $\$ 50$ million in products and processes, which are based on INL patented technologies Since 2005, INL has:

- Generated 808 invention disclosure records, filed 396 patent applications and received 361 issued patents.

- In FY2013, 32 Invention Disclosure Records were submitted and 39 patents were issued to INL.

- Earned more than $\$ 11$ million in royalties from nearly 838 licensed technologies, including $\$ 1.55$ million dollars during 2013.

- In FY2013, 94 licenses were executed; including 2 new and 17 modified patent licenses, 35 new RELAP licenses and 57 other software copyright licenses.

- Signed 132 new Cooperative Research and Development Agreements (CRADAs) valued at nearly $\$ 300$ million.

- During FY2013, 15 new CRADAs were signed and 21 were modified at a value of $\$ 51$ million.

- Attracted 376 projects representing nearly $\$ 1.3$ billion in our contracted non-DOE Work For Others (WFO) programs.

- In FY2013, 29 new projects were added and more than 300 projects were modified at a value of $\$ 107$ million.

While FY2013 is now a memory, our attention is focused on a new year and the continuing challenges in deploying INL technologies - patented inventions, copyrighted software applications, and new discoveries in shared cooperative research agreements.

Our goal is to leverage renewed capabilities at INL to create more advances, innovations and discoveries. In taking on the challenge of moving innovation from bench scale research to the commercial marketplaces of America, INL aspires to have an impact by helping make America energy systems safer and more competitive.

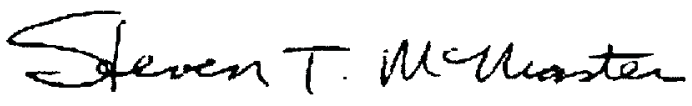

Steven T. McMaster

Director, Technology Deployment 

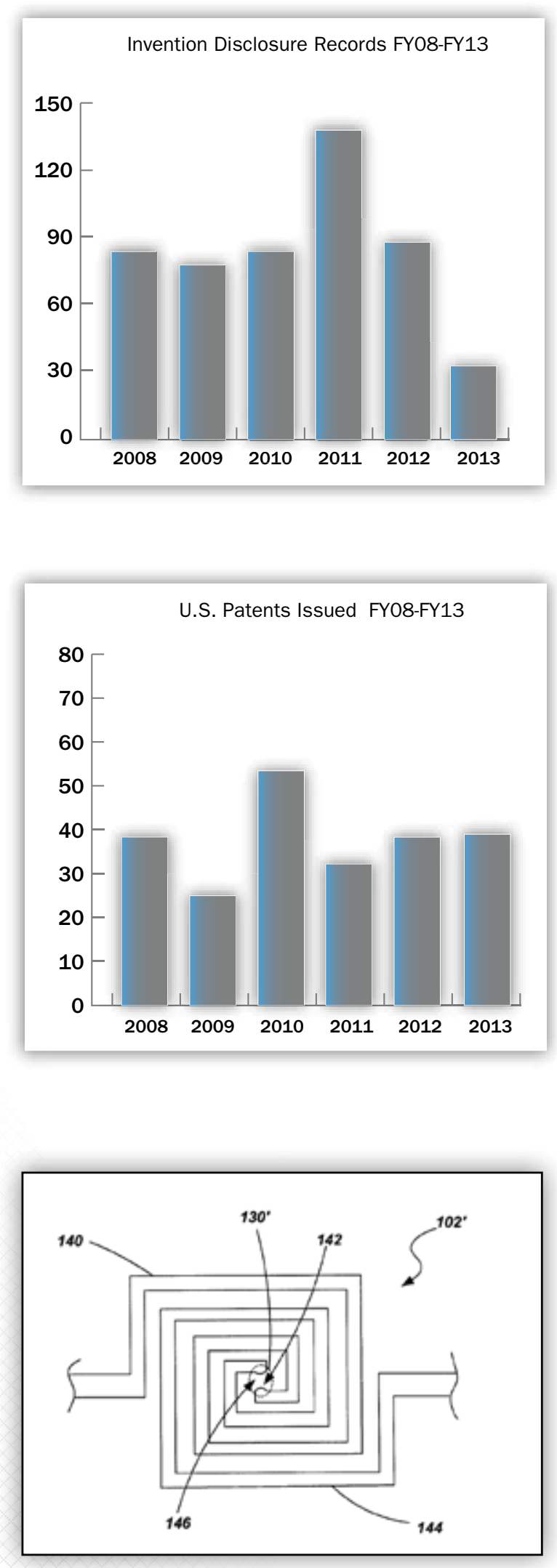

\section{Intellectual Property}

Idaho National Laboratory's portfolio of Intellectual Property (IP) includes requested and granted copyright assertions, filed patent applications and issued patents. This IP often serves as a basis for working with national laboratories and federal agencies, commercial enterprises, academia and other parties. IP portfolios are a key measure of the institution's ability to do creative, meaningful research.

Technology Deployment (TD) works closely with researchers and management of INL's directorates to identify and pursue technology commercialization and business development opportunities.

In 2013, 32 Invention Disclosures Records (IDRs) were submitted to Battelle Energy Alliance (BEA) by INL inventors. These include 10 from Energy and Environment Science and Technology (EEST), 7 from Nuclear Science and Technology (NST), 14 from National and Homeland Security Science and Technology (NHS) and 1 from another INL department.

Thirty-nine U.S. patents were issued either to INL or DOE based on the inventions of INL scientists and researchers. These included 26 from EEST, 3 from NST and 10 from NHS.

In addition, BEA and DOE filed 21 new patent applications, including 18 from EEST, 1 from NST and 2 from NHS.

During the past nine years, INL researchers have generated 808 IDRs, filed 396 U.S. patent applications and received 361 U.S. issued patents.

BEA has the right under its contract, subject to some exceptions, to take title to inventions and seek patent protection. The decision of whether or not to take title and seek patent protection is based on market and technical assessments of the technology and its subsequent programmatic value. Market assessments are performed and a recommendation is presented to a committee comprised of department or project managers, assistant lab director or designee, market analysts, commercialization managers, and patent attorneys. These recommendations are presented before the team and then a final decision is made to elect or decline the technology for patent protection by TD's director. Generally, if the invention is judged as commercially valuable, crucial to a primary mission, or valuable in terms of motivating further research funding, it is elected. If BEA decides to decline title, DOE decides whether to seek patent protection in its own name. If DOE decides not to seek patent protection, the inventor(s) may petition to have title waived to them by DOE with the expectation that they will pursue patent protection using their own resources.

A brief description of the 39 patents issued to INL inventors during FY 2013 is provided on the following pages.

\section{Energy Harvesting Devices for Harvesting Energy from Terahertz Electromagnetic Radiation}

A patent was issued for this invention to Steven Novack, Dale Kotter, and Patrick Pinhero. Also called the Nanoantenna, this invention provides a passive energy harvesting technology that promises to be a cost effective, energy efficient, alternative to current solar photovoltaic (PV) methods. Nanoantenna arrays, developed on flexible substrates, directly convert electromagnetic radiation (for example ultraviolet, visible and infrared) to electrical energy.

Nanoantenna Array structures can be built without the use of silicon on flexible substrates such as polyethylene, making the manufacturing of large scale products inexpensive and adaptable for flexible products.

Patent Number: 8,283,619

Issued: Oct. 9, 2012 


\section{Chemical Reactor for Converting a First Material into a Second Material}

Peter Kong received a patent for this invention, which may be used to store hydrogen for fuel cell-powered vehicles. This hybrid combustion flame-arc system may be as much as 50 percent more economical than plasma-plasma systems that convert borax into sodium borohydride.

Patent Number: 8,287,814

Issued: Oct. 16, 2012

\section{Molten Metal Reactor and Method of Forming Hydrogen, Carbon Monoxide, and Carbon Dioxide using the Molten Alkaline Metal Reactor}

A patent was issued to Dennis Bingham, Kerry Klingler, Terry Turner, and Bruce Wilding for this invention, which describes a process that uses a carbon based feedstock (called vacuum residual) and transforms this material with water into hydrogen, carbon monoxide, and carbon dioxide. This process seeks to economically provide pressurized hydrogen, carbon monoxide and carbon dioxide gas streams that are collectively or independently usable products for upgrading petroleum.

Patent Number: 8,309,049

Issued: Nov. 13, 2012

\section{Methods for Recovering a Polar Solvent from a Fluid Stream Contaminated with at Least One Polar Impurity}

A patent was issued to Daniel Ginosar and Daniel Wendt for this invention, which aids in making biodiesel from vegetable or animal oils. Free fatty acids (e.g. animal and/or vegetable lipids) can be extracted from a waste oil stream to produce a clean oil stream that can be used for making biodiesel.

This invention allows pure alcohol to be recovered by expanding the mixture with a near critical gas (e.g. carbon dioxide). After a minor drop in pressure, the pure alcohol can be recovered and reused in the extraction process or in other processes for making biodiesel. This process decreases waste production and increases the supply of renewable fuels, sending less waste to landfills or waste treatment plants, while offering potential reductions in $\mathrm{CO} 2$ emissions.

Patent Number: 8,308,954

Issued: Nov. 13, 2012

\section{Methods of Forming Single Source Precursors, Methods of Forming Polymeric Single Source Precursors, and Single Source Precursors and Intermediate Products Formed by Such Methods}

TThis patent was issued to Robert Fox, Rene Rodriguez, Joshua Pak, Chivin Sun, Kelsey Margulieux, and Andrew Holland. Reduced to practice under a CRADA with Precision Nanoparticles Company, this invention simplified a process for producing organic/metallic single source precursors used to manufacture photovoltaics.

Patent Number: 8,324,414

Issued: Dec. 4, 2012
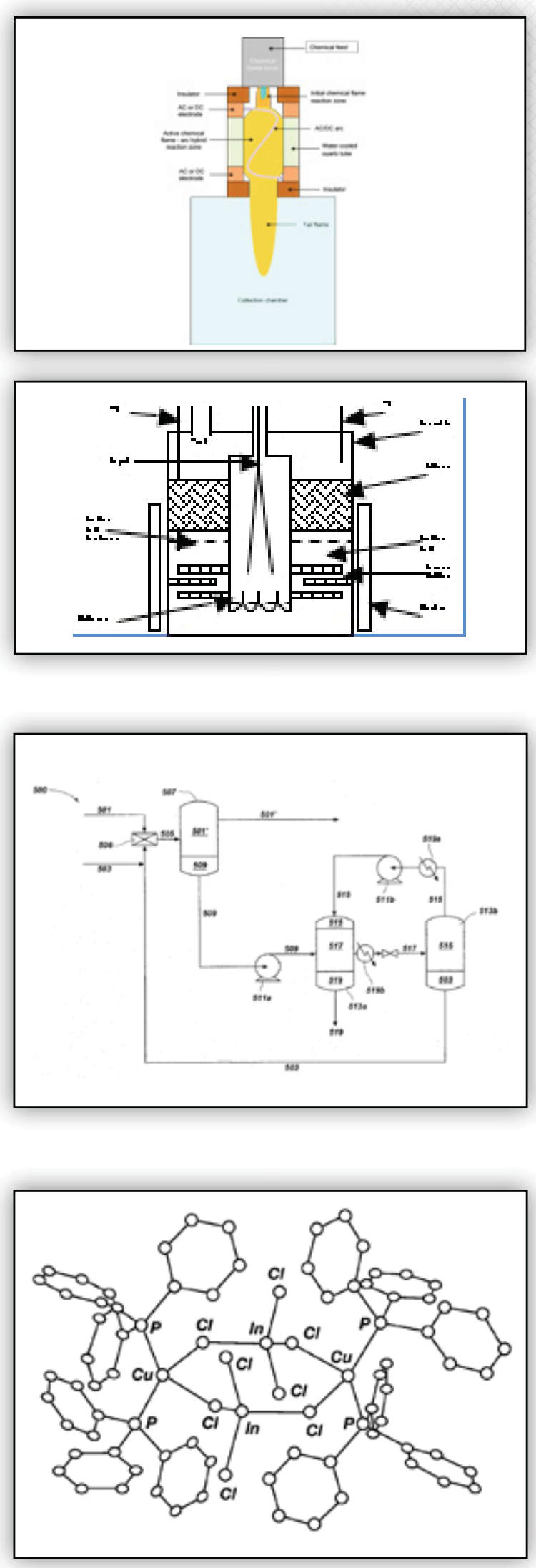

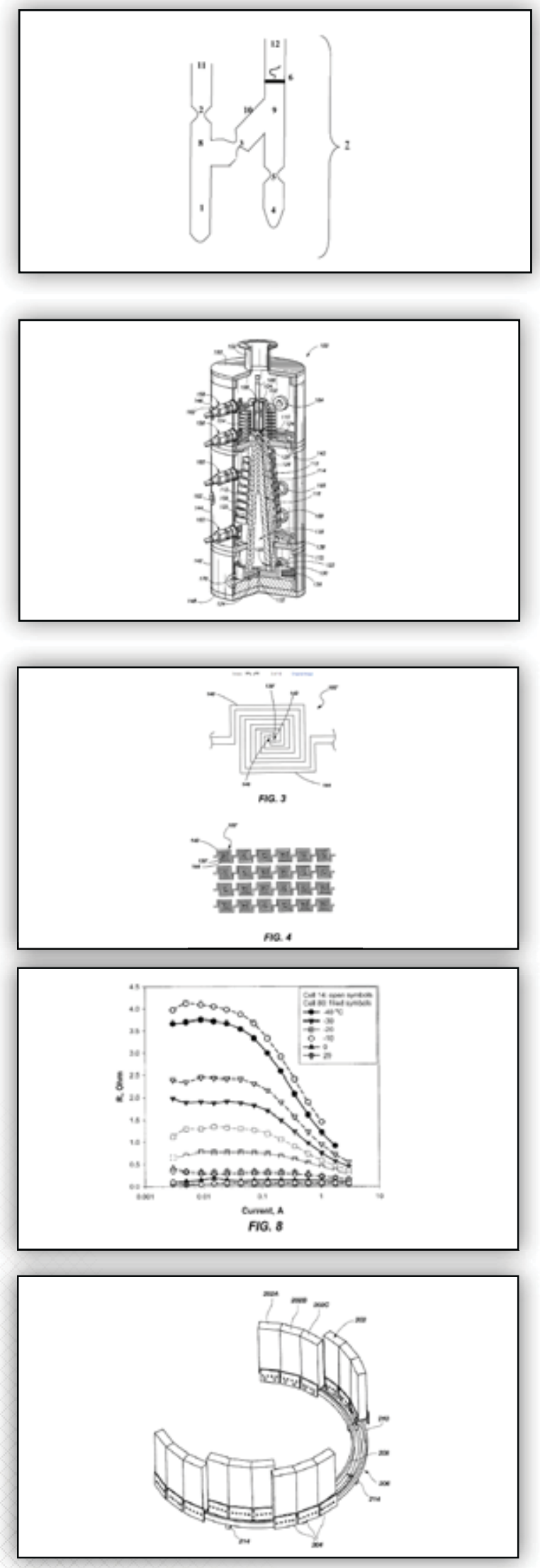

\section{Method for Production of an Isotopically Enriched Compound}

Issued to Matthew Watrous, this patent teaches the production of pure Xenon 131 with significantly less starting material and uses fewer steps than the previous state of the art. Xenon is used as a light source in special applications and a fill gas for thyraton tubes used for igniting nuclear weapons and half-wave rectifier tubes.

Patent Number: 8,329,122B1 Issued: Dec. 11, 2012

\section{Casting Methods}

Granted to Kenneth Marsden, Mitchell Meyer, Blair Grover, Randall Fielding and Billy Wolfensberger, this patent is for a casting system that remotely fabricates nuclear fuel slugs. This system is a reusable crucible that has very low losses of volatile actinides and generates much less waste than previous systems.

Patent Number: 8,333,230

Issued: Dec. 18, 2012

\section{Devices, Systems, and Methods for Harvesting Energy and Methods for Forming Such Devices}

Issued to Dale Kotter and Steven Novack, this patent describes the design of a novel energy harvester that collects energy between the $20 \mathrm{THz}$ and $1,000 \mathrm{THz}$ ranges of light spectrum. The invention is novel because it collects energy from non-traditional sources of light which are more plentiful and consistent than the bright sunlight traditionally associated with solar panels.

Patent Number: 8,338,772 Issued: Dec. 25, 2012

\section{Systems, Methods And Computer Readable Media To Model Kinetic Performance Of Rechargeable Electrochemical Devices}

This patent was issued to Kevin Gering and teaches modeling capability that more accurately determines, track, diagnoses, and predicts kinetic performance in electrochemical cells and batteries. Kinetic performance limitations are directly related to cell chemistry and this patent teach methods to more accurately model battery cells.

Patent Number: 8,346,495 Issued: Jan. 1, 2013

\section{Composite Armor, Armor System and Vehicle Including Armor System}

Issued to Henry Chu, Warren Jones, Jeffrey Lacy, and Gary Thinnes, this patent describes a novel composite, lightweight and configurable armor panel, which can be applied as a cupola to provide a supplemental protective enclosure on existing and future military vehicles.

Patent Number: 8,342,073

Issued: Jan. 1, 2013 


\section{A Device for Collecting Chemical Compounds and Related Methods}

Granted to Jill Scott, Gary Groenewold, and Catherine Rae, this patent teaches a novel design for a piece of a portable chemical extraction device used to collect and transport compounds for analysis. This device is meant to capture volatile chemical compounds for analysis.

Patent Number: 8,342,042

Issued: Jan. 1, 2013

\section{Method of Detecting System Function by Measuring Frequency Response}

Issued to John Morrison, William Morrison, Jon Christophersen, and Chet Motloch, this patent teaches the method of rapidly measuring the impedance spectrum of an energy storage device. This technique significantly reduces the time required to acquire data compared to conventional methods and represents exceptional advances in sensor technology for in-situ battery state of health assessment.

Patent Number 8,352,204

Issued: Jan. 8, 2013

\section{Image Portion Identification Methods, Image Parsing Methods, Image Parsing Systems, and Articles of Manufacture}

Issued to Gordon Lassahn, Gregory Lancaster, William Apel, and Vicki Thompson this patent describes methods for processing digital images taken of biological substances that have unique patterns, similar to those of DNA profiles. It also automatically identifies portions of the image which have a matching biological profile from an image database. This is part of the Antibody Profiling Identification invention, licensed by Identity Sciences, Ltd.

Patent Number: 8,351,674

Issued: Jan. 8, 2013

\section{Robots, Systems, and Methods for Hazard Evaluation and Visualization}

This patent was issued to Curtis Nielsen, David Bruemmer, Miles Walton, Scott Hartley, David Gertman, Robert Kinoshita, and Jonathon Whetten. It identifies systems and methods that enable robots to autonomously scan for and detect hazards, communicate the hazard to a control station, and graphically display the location and intensity of the hazard to an operator. Hazards include such things as dangerous chemicals, radiological contamination, and explosives.

Patent Number: 8,355,818

Issued: Jan. 15, 2013

\section{Composite Materials and Bodies, including Silicon Carbide and Titanium Diboride and Method of Forming Same}

Issued to Thomas Lillo, Henry Chu, William Harrison and Derek Bailey, this patent teaches the material formation and composition of novel armor construction.

Patent Number: $8,357,623 \mathrm{~B} 2$
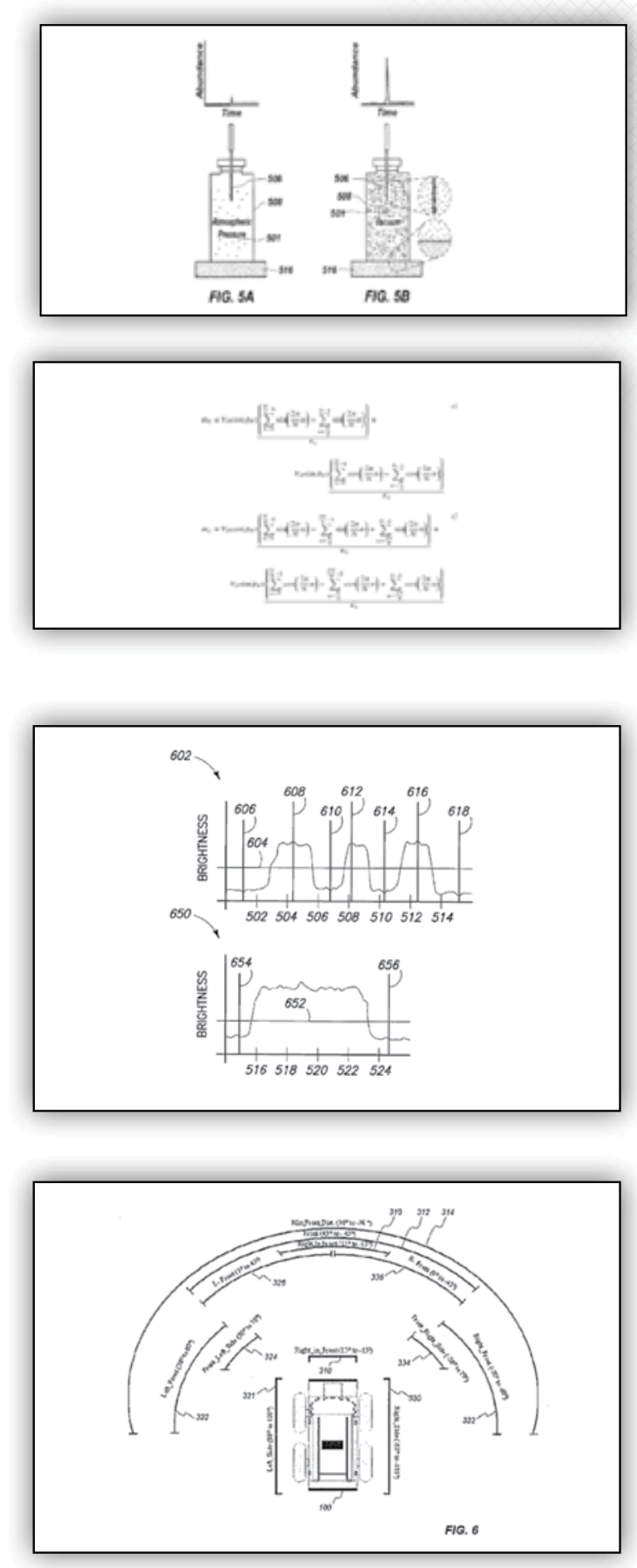
The research team of David Thompson, William Apel, Vicki Thompson, David Reed, and Jeffrey Lacey were issued five patents during the year that are associated with continuing research for licensee, Xtreme Biochemicals. In some cases they were joined by an additional researcher or two. For one other patent, the Thompsons and William Apel were joined by another researcher.

All of these patents contribute to a technology that aids in chemically breaking down biomass for use in fuels. Those patents issued during FY2013 include (added team members are noted in the listing):

Thermophilic and Thermoacidophilic Sugar Transporter Genes and Enzymes from Alicyclobacillus Acidocaldarius and Related Organisms, Methods

Patent Number: 8,354,517 Issued: Jan. 15, 2013

Thermophilic and Thermoacidophilic Sugar Transporter Genes and Enzymes from Alicyclobacillus Acidocaldarius and Related Organisms, Methods

Patent Number: 8,362,226 Issued: Jan. 29, 2013

Thermophilic and Thermoacidophilic Biopolymer-Degrading Genes and Enzymes from Alicyclobacillus Acidocaldarius and Related Organisms, Methods

Emily Henriksen joined the team to invent this technology.

Patent Number: 8,426,185 Issued: April 23, 2013

Thermal and Acid Tolerant BETA Xylosidases, Arabinofuranosidases, Genes Encoding, Related Organisms and Methods

Kastli Schaller joined the team for this patent.

Patent Number: 8,431,379 Issued: April 30, 2013

Method of Combined Bioprocessing and Related Microorganisms, Thermophilic and/or Acidophilic Enzymes, and Nucleic Acids Encoding said Enzymes

Thomas Ward joined the Vicki Thompson, David Thompson and William Apel in this invention.

Patent Number: 8,492,114 Issued: July 23, 2013

Thermophilic and Thermoacidophilic Biopolymer-Degrading Genes and Enzymes from Alicyclobacillus Acidocaldarius and Related Organisms, Methods

Emily Henriksen also joined the team for this patent.

Patent Number: 8,497,110B2 Issued: July 30, 2013 


\section{Methods and Systems for Producing Syngas}

A patent for this invention was issued to Grant Hawkes, James O’Brien, Carl Stoots, Stephen Herring, Michael McKellar, Richard Wood, Robert Carrington and Richard Boardman.

This patent teaches methods to produce syngas by using thermochemical conversion of carbonaceous fuels to produce heat in support of solid-oxide electrolysis cells. A portion of the oxygen produced by reducing water and carbon dioxide is directed toward the thermochemical conversion of the fuel to control the ratio of carbon dioxide and carbon monoxide produced during the process.

Patent Number: 8,366,902

Issued: Feb. 5, 2013

\section{Methods of Producing Armor Systems and Armor Systems Produced Using Such Methods}

Issued to Henry Chu, Thomas Lillo and Kevin McHugh, this patent teaches a novel method to construct armor. The armor is constructed using spray forming techniques which improves material properties.

Patent Number: 8,377,512

Issued: Feb. 19, 2013

\section{Charged Particle Detectors with Active Detector} Surface for Partial Energy Deposition of the Charged Particles and Related Methods

Issued to David Gerts, Robert Bean, and Richard Metcalf, this patent teaches methods and design of a novel radiation detector. The detector uses data timing between active detector surfaces to determine the energy of the incident radiation.

Patent Number: 8,378,308

Issued: Feb. 19, 2013

\section{Laminate Armor and Related Methods}

Granted to Henry Chu, Thomas Lillo and Thomas Zagula, this patent teaches a method of manufacture for laminated armors that increases desirable material properties. This manufacturing process reduces the amount of expensive materials needed like titanium, while maintaining strength and lightweight properties.

Patent Number: 8,381,631

Issued: February 26, 2013
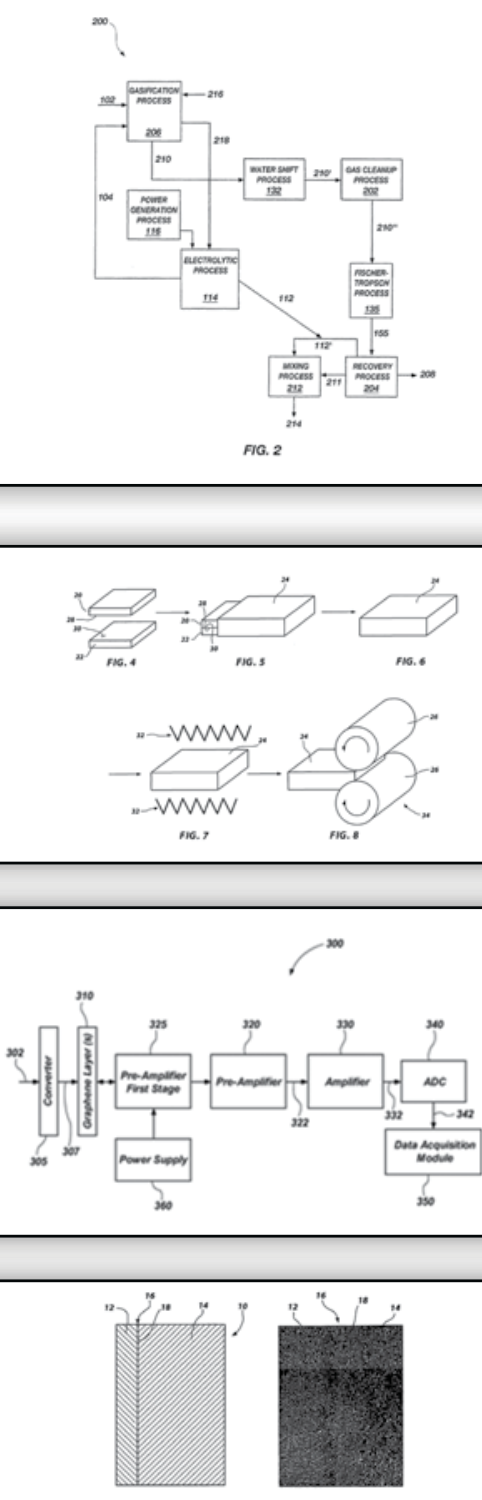

FIG. $\quad$ FIG.3

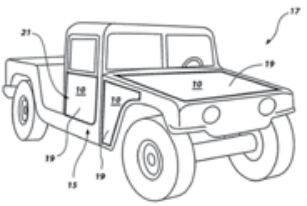



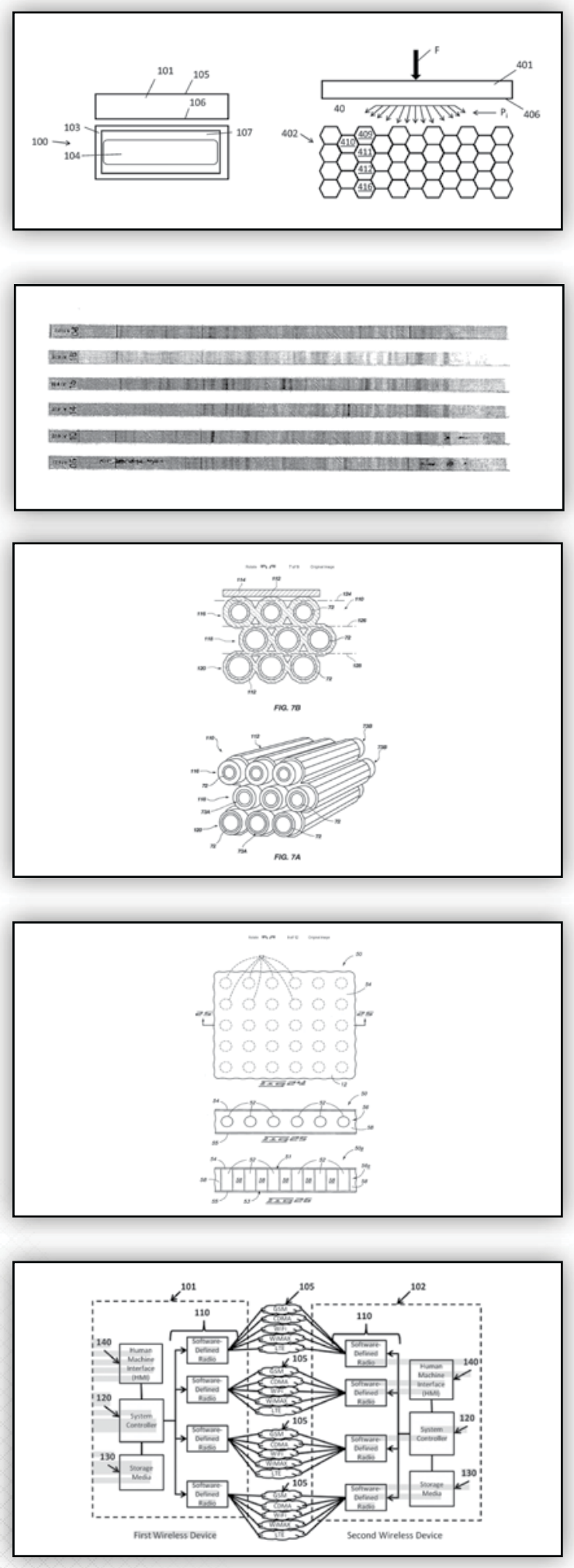

\section{Lightweight Armor System}

Granted to Henry Chu, Benjamin Langhorst, Michael Bakas, and Gary Thinnes, this armor design uses a layered system that breaks up incoming projectiles, dissipates their energy, and then cushions the impact using a hydrogel layer. The armor system proposed consists of a lightweight vest designed to be reinforced with protective plates using the layered design.

Patent Number: 8,381,632

Issued: Feb. 26, 2013

\section{Antibody Profiling Sensitivity through Increased Reporter Antibody Layering}

Re-issued to William Apel and Vicki Thompson, this patent supports technology that quickly screens human antibodies for positive identification using saliva rather than blood or urine samples.

Patent Number: RE44,031

Issued: Feb. 26, 2013

\section{Electrolytic/Fuel Cell Bundles and Systems Including a Current Collector in Communication with an Electrode Thereof}

Issued to Grant Hawkes, Stephen Herring, Carl Stoots, and James O'Brien, this patent teaches how to implement fuel bundles in solid oxide fuel cells. The design improves fuel cell performance, while diminishing fuel degradation.

Patent Number: 8,389,180 Issued: March 5, 2013

\section{Combustible Structural Composites and Methods of Forming Combustible Structural Composites}

Granted to Michael Daniels, Ronald Heaps, Eric Steffler, and David Swank, this patent describes a combustible structural composite that may be used by the military when an asset (e.g. vehicle or structure) is no longer needed, but should not be left to an enemy. The combustible structural composite would be ignited and the asset would be rendered unusable.

Patent Number: 8,409,377 Issued: April 2, 2013

\section{Communication Devices for Network-Hopping Communications and Methods of Network-Hopping Communications}

Issued to John Buttles, this patent describes methods for faster transmission rates and more secure communication methods for multipoint networks.

Patent Number: 8,428,038

Issued: April 23, 2013 


\section{Methods of Forming Semiconductor Devices and Devices Formed Using Such Methods}

Granted to Robert Fox, Rene Rodriguez and Joshua Pak, this patent teaches that single source precursors subjected to carbon dioxide in a supercritical state may form nanoparticle material. The methods may be used in forming semiconductors for various uses, including photo voltaic materials.

Patent Number: 8,445,388

Issued: May 21, 2013

\section{Method and System for Producing Hydrogen Using Sodium Ion Separation Membranes}

Issued Dennis Bingham, Kerry Klingler, Terry Turner, Bruce Wilding and Lyman Frost, this patent teaches how to create hydrogen from sodium hydroxide and water using different liquid sodium hydroxide solutions in ion separators with a ceramic membrane that is manipulated by an electric charge. The sodium cations then transport across the membrane and combine with an electron to form elemental sodium.

Patent Number: 8,444,846

Issued: May 21, 2013

\section{Systems, Methods and Computer Readable Media for Estimating Capacity Loss in Rechargable Electrochemical Cells}

Issued to Kevin Gering, this patent describes methods and modeling capability that better predicts the capacity loss in a battery. Aging batteries deteriorate in their ability to store and deliver energy, diminishing suitability for their intended application. This patent more accurately determines, tracks, diagnoses, and predicts capacity loss in electrochemical cells and batteries.

Patent Number: $8,467,984$

Issued: June 18, 2013

\section{Autonomous Grain Combine Control System}

Issued to Reed Hoskinson, Kevin Kenney, James Lucas, and Marvin Prickel, this patent teaches systems for autonomously controlling the adjustment of operating conditions in a grain combine to optimize the harvest of a grain crop.

Patent Number: 8,469,784

Issued: June 25, 2013

\section{Process for the Production of Uranium Chloride Salt}

Issued to Brian Westphal and Robert Mariani, this patent teaches a process for producing uranium chloride.

Patent Number: 8,475,756

Issued: July 2, 2013
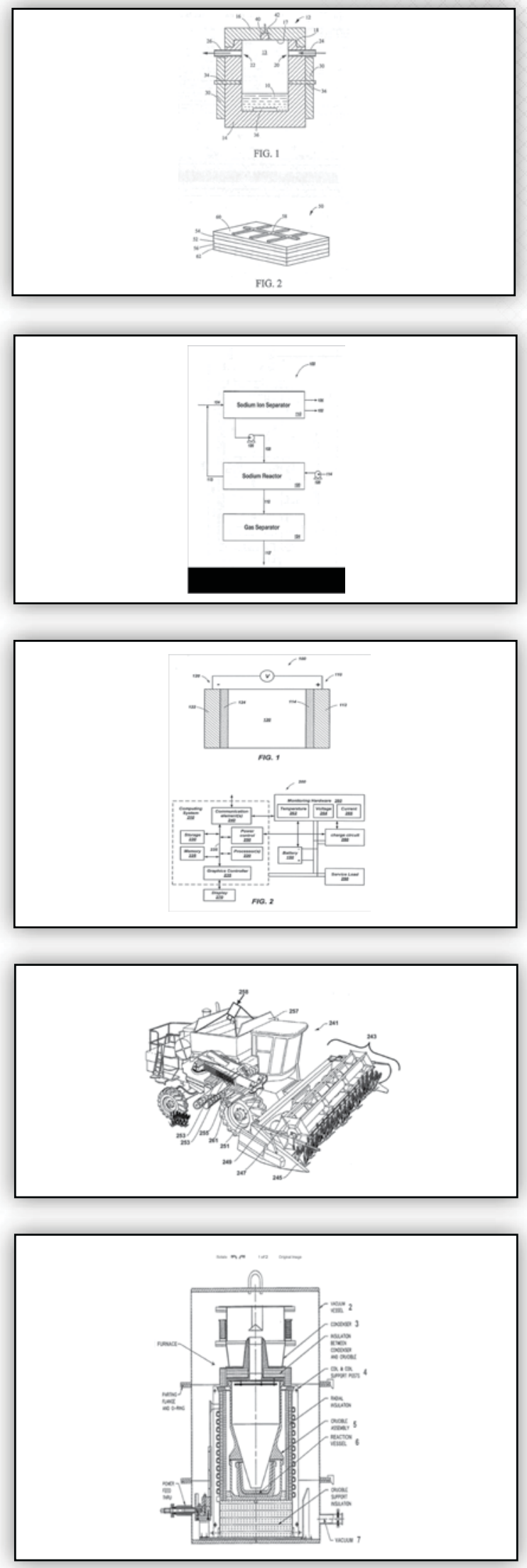

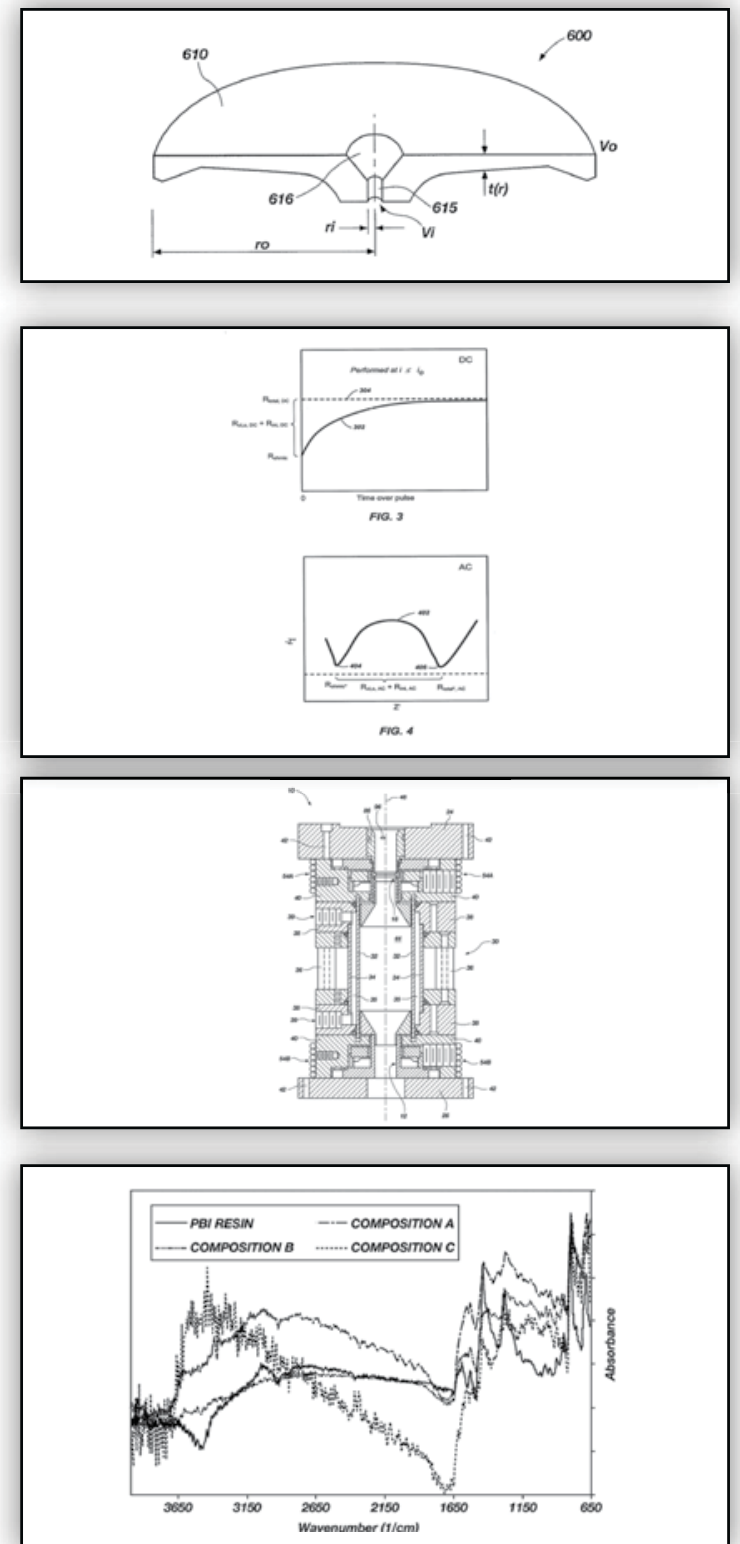

\section{Apparatuses and Methods for Generating Electric Fields}

Granted to Jill Scott, Timothy McJunkin, and Paul Tremblay, this patent describes a novel design for an electric field generator in mass spectroscopy applications that directs charged particles located outside the center of the aperture toward the center of the aperture for spectroscopic analysis.

Patent Number: 8,502,159 Issued: Aug. 6, 2013

\section{Systems, Methods and Computer Readable Media for Modeling Cell Performance Fade of Rechargeable Electrochemical Devices}

Issued to Kevin Gering, this patent describes a modeling method that more accurately determines, tracks, diagnoses, and predicts cell conductance characteristics in electrochemical cells and batteries.

Patent Number: 8,521,497

Issued: Aug. 27, 2013

\section{Electrode Assemblies, Plasma Apparatuses and Systems, including Electrode Assemblies, and Methods for Generating Plasma}

Granted to Peter Kong, Jon Grandy, Brent Detering, and Larry Zuck, this patent describes the placement of electrodes in a plasma generator to obtain higher residence time and greater efficiency by isolating and utilizing magnetic fields.

Patent Number: 8,536,481 Issued: Sep. 17, 2013

\section{Polymer Compositions, Polymer Films and Methods and Precursors for Forming Same}

Issued to John Klaehn, Eric Peterson, and Christopher Orme, this patent describes the polymer composition of a novel blended polybenzimidazole (PBI) thermoset. This new PBI thermoset is a stable, high performance polymer blend that includes $\mathrm{PBI}$ and a melamine-formaldehyde polymer for forming structures such as films and fibers.

Patent Number: 8,541,517

Issued: Sep. 24, 2013

"This year the Technology Deployment (TD) department has focused on deploying a number of these new software tools and safeguards. The interest in RELAP5$3 D$ has continued to grow and 35 new licenses have made this invaluable safety, design and training code available to more in the nuclear industry. But other new software has emerged quickly and in answer to divergent needs. " 


\section{Granted Copyrights}

INL received permission to assert copyright for 21 newly developed software - 17 for National and Homeland Security and 4 for Energy and Environment.

\begin{tabular}{|c|c|}
\hline Copyrighted Software & Authors \\
\hline OgINet Version 13 (Sophia) & $\begin{array}{l}\text { Jared Verba, Gordon Rueff, Kenneth Rohde, Corey Thuen, } \\
\text { Robert Erbes, Scott Brown, Daniel Campbell }\end{array}$ \\
\hline Packet Daemon Version 13 (Sophia) & Jared Verba, Gordon Rueff, Kenneth Rohde, Corey Thuen \\
\hline Packet Library Version 13 (Sophia) & Jared Verba, Gordon Rueff, Kenneth Rohde, Corey Thuen \\
\hline Sophia Client Version 13 & Jared Verba, Gordon Rueff, Kenneth Rohde, Corey Thuen \\
\hline Sophia Daemon Version 13 & $\begin{array}{l}\text { Jared Verba, Gordon Rueff, Kenneth Rohde, Corey Thuen, } \\
\text { Robert Erbes }\end{array}$ \\
\hline Sophia Library Version 13 & Jared Verba, Gordon Rueff, Kenneth Rohde, Corey Thuen \\
\hline SophiNet Version 13 & $\begin{array}{l}\text { Jared Verba, Gordon Rueff, Kenneth Rohde, Corey Thuen, } \\
\text { Robert Erbes, Scott Brown, }\end{array}$ \\
\hline Sophia Support Version 13 & $\begin{array}{l}\text { Jared Verba, Gordon Rueff, Kenneth Rohde, Corey Thuen, } \\
\text { Robert Erbes, Scott Brown, Kent Kvarfordt }\end{array}$ \\
\hline Underwire Version 13 (Sophia) & $\begin{array}{l}\text { Jared Verba, Gordon Rueff, Kenneth Rohde, Corey Thuen, } \\
\text { Robert Erbes }\end{array}$ \\
\hline VruiNet Version 13 (Sophia) & Gordon Rueff, Scott Brown \\
\hline Integrated Waste Tracking System (IWTS) & $\begin{array}{l}\text { Robert Anderson, David Hutchison, Kirk Green, Patricia } \\
\text { Loo, Richard Powell, Brian Seggerty, Craig Bates, Jonathan } \\
\text { Cantu, Juan Garcia, Justin Tozer, Kent Klingler, Michael } \\
\text { Landon, Scott Auvil }\end{array}$ \\
\hline $\begin{array}{l}\text { Automatic Energy Calibration of Gamma-Ray } \\
\text { Spectrometers (Auto E-Cal) }\end{array}$ & Augustine Caffrey, Ann Egger, Kenneth Krebs, David Caffrey \\
\hline GAUSS Algorithms & Ann Egger \\
\hline $\begin{array}{l}\text { Portable Isotopic Neutron Spectroscopy High Explosive } \\
\text { Identification Software (PINS-3X) }\end{array}$ & $\begin{array}{l}\text { Kenneth Krebs, Augustine Caffrey, Ann Egger, Edward } \\
\text { Seabury, Clinton Van Siclen }\end{array}$ \\
\hline $\begin{array}{l}\text { Portable Isotopic Neutron Spectroscopy Chemical } \\
\text { Weapons Identification Software (PINS-3C) }\end{array}$ & $\begin{array}{l}\text { Kenneth Krebs, Augustine Caffrey, Ann Egger, Clinton Van } \\
\text { Siclen }\end{array}$ \\
\hline Sensor Authentication: Embedded Processor Code & John Svoboda \\
\hline Sensor Authentication: Graphical User Interface Code & John Svoboda \\
\hline Coal-to-Liquids Process Model & Richard Wood, Richard Boardman, Anastasia Gandrik \\
\hline Updraft Fixed Bed Gasification Aspen Plus Mode & Anastasia Gandrik, Richard Wood \\
\hline $\begin{array}{l}\text { Generalized Environment for Modeling Systems } \\
\text { (GEMS) }\end{array}$ & Sam Alessi, David McGrath \\
\hline MarmotViz & Alexander Rattner, Donna Guillen \\
\hline
\end{tabular}




\section{License Highlights}

License agreements between BEA and business allow the business to reproduce, manufacture, sell, or use INL developed or owned intellectual property. INL contractor-managed inventions are available for license by private businesses for commercialization. INL licenses its intellectual property on much the same terms as universities, other research organizations and industrials firms.

During the past nine years, INL has signed more than 655 new license agreements, extended 183 existing agreements, and earned from these agreements more than $\$ 11$ million in royalties. There were 215 new and modified fee-bearing licenses during the past five fiscal years (FY), ranging from 24 in FY2010 to 50 in FY2013, highlighted in the accompanying graph. This activity represents significant licensing efforts and underscored by increased copyright licensing interest.

In FY2013, INL signed a total of 94 new agreements and amended another 32 agreements. These included a total of 19 patent licenses - 2 new licenses, 6 modifications, 2 new option agreements, and 9 modified option agreements. INL executed a total of 107 copyright licenses that included 90 new licenses and 17 modifications. Of those licenses, 31 of the copyright licenses were fee-bearing and 76 were provided without fees, primarily to universities and government entities.

RELAP5-3D licensing remained strong in FY2013 with 50 licenses (35 new licenses, 15 modifications) being executed. Eight other software packages accounted for 57 license agreements ( 55 new copyright licenses and 2 modifications).

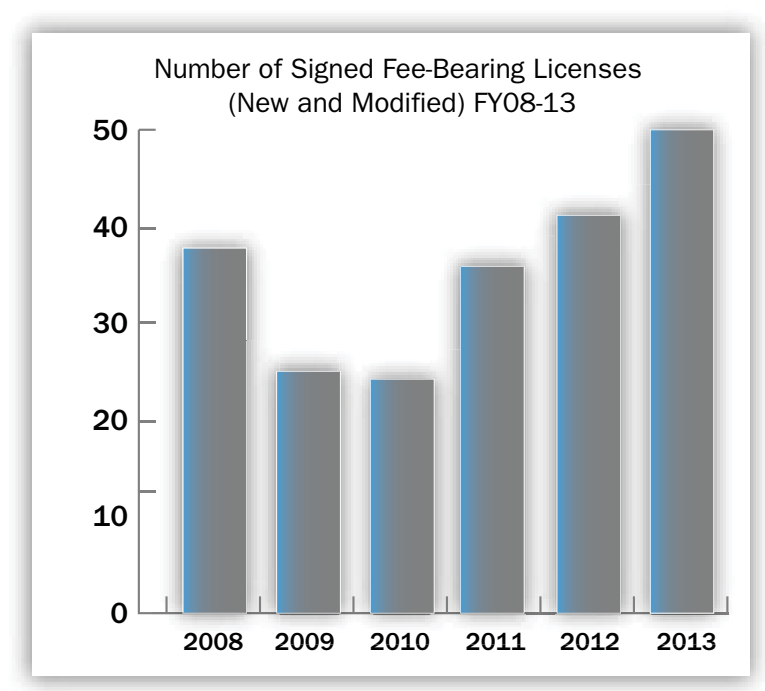

The following summarizes selected licenses, options and modified agreements, featuring significant activity in software.

Advanced Measurement Technology, Inc. (AMETEK): Signs License for INL's PINS Chemical Identification technology

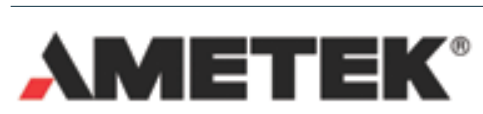

AMETEK signed a long-term, exclusive license for INL's Portable Isotopic Neutron

Spectroscopy (PINS) Chemical Identification technology. This version of PINS nondestructively identifies the presence of chemical warfare agents, explosives, smoke-generating chemicals, and other substances in closed containers. PINS uses neutrons, a very penetrating form of radiation, to interrogate containers and munitions, to avoid the need to open, or even touch, containers. Applications for this technology are primarily military, including recovered ordnance identification, treaty verification, and antiterrorism.
Porifera Inc.:

Signs License Option on Forward Osmosis Technology

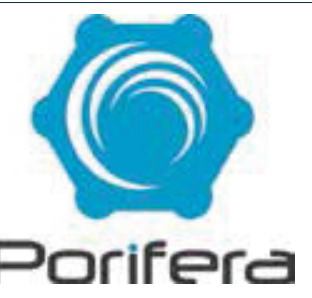

Porifera Inc., a U.S.-based startup, has executed a license option agreement for rights to a unique forward osmosis draw solute under the Startup America Program. The technology, Switchable Polarity Solvent Forward Osmosis (SPS FO), offers the potential for aiding industry in processing water for reuse in various operations. Porifera will be exploring opportunities for the technology to address several challenging applications.

Western Hydrogen:

Executes a License Option and a Modification

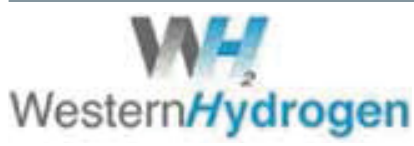

Western Hydrogen executed a license option agreement for foreign patents of interest in the commercialization of the technology for gas liquiefaction and hydrogen production. A modification to the existing license was also executed to update licensed patents. 
Selected summary of INL patent licensing activity.

\begin{tabular}{|c|c|}
\hline Licensee & Technology \\
\hline AMETEK, Inc. & $\begin{array}{l}\text { Portable Induced Neuron Spectroscopy for Chemical Warfare } \\
\text { Species Identification (PINS) (new patent license) }\end{array}$ \\
\hline 5D Robotics, inc. & Robotic Intelligence Kernel (modified patent license) \\
\hline LNG Energy Solutions, Inc. & Liquefaction fo Natural Gas Methods (modified patent license) \\
\hline CINC Indusutries & Microwave-Emitting Rotor, Separator Apparatus (modified patent license) \\
\hline Western Hydrogen Limited & $\begin{array}{l}\text { Method of Liquefying a Gas, Producing Hydrogen, Producing High Pressure Gas, } \\
\text { and Producing Hydrogen Using Sodium Ion Separation Membranes } \\
\text { (modified patent license) }\end{array}$ \\
\hline Torion Technologies, Inc. & Devices for Collecting Chemical Compounds (modified patent license) \\
\hline Optisense Network, Inc. & Electro-Optic High Voltage Sensor (modified patent license) \\
\hline Xtreme Biochemicals, Inc. & Enzyme and Methodology for Treatment of Biomass (modified patent license) \\
\hline BKS Energy, LLC & $\begin{array}{l}\text { Application to Process Vectored Natural Gas from a Pipleline } \\
\text { (modified patent license) }\end{array}$ \\
\hline The NanoSteel Company, Inc. & Methods of Forming Steel (modified patent license) \\
\hline Porifera, Inc. & Treating Switchable Solvents (new license option) \\
\hline Western Hydrogen Limited & $\begin{array}{l}\text { Method for Producing Hydrogen Using Sodium Ion Separation Membranes } \\
\text { (new license option) }\end{array}$ \\
\hline RedWave Energy, Inc. & $\begin{array}{l}\text { Methods for Harvesting Energy from Electromagnetic Radiation } \\
\text { (modified option license) }\end{array}$ \\
\hline Hydration Technology innovations & $\begin{array}{l}\text { Methods for Treating Liquids Using Switchable Solvents } \\
\text { (modified option license) }\end{array}$ \\
\hline LNG Energy Solutions, Inc. & Apparatus for Liquefaction fo Natural Gas (modified option license) \\
\hline Identity Sciences, LLC & $\begin{array}{l}\text { Identification of Discriminant Proteins through Antibody Profiling } \\
\text { (modified option license) }\end{array}$ \\
\hline
\end{tabular}

"During the past nine years, INL has signed more than 655 new technology

license agreements. TD continues to do good work in negotiating and leveraging

INL innovation through Collaborative Research and Development Agreements

(CRADAs) and Work for Other (WFO) agreements."

John J. Grossenbacher

Director, Idaho National Laboratory 


\section{INL's Copyright Licensing Grows Significantly}

\section{By Keith Arterburn}

The digital world continues to expand at a rapid pace requiring more innovation, greater attention to security and more aggressive licensing practices by national laboratories. Emerging technologies are dominated by software and copyrighted innovations that require responses at electron speeds to provide the best return on investment for U.S. taxpayers and satisfactory service to government and private-sector customers.

"Several years ago, Technology Deployment began investing in streamlining processes and developing new, 'best in class' standards in anticipation of the accelerated expectations of the digital business environment," said Jason Stolworthy, deputy director of Technology Deployment. "These creative investments are now paying dividends, evident from this summary of rapidly increasing licensing of software and copyrighted innovations. INL's increased distribution of software greatly expands the impact of INL's research and advancement of Nuclear Energy."

For example, software licensing now is accomplished efficiently, often resulting in signed licenses within 14-20 processing days.

These new processes are resulting in higher rates of deployed INL software. Not long ago licensing for the Reactor Excursion and Leak Analysis Program, better known as RELAP, often numbered only 2-3 new licenses per year. Now, INL, in partnership with the International RELAP Users Group (IRUG), processes 30 or 40 new licenses annually and experienced strong attendance by users during a three-day training during Sept., held in Idaho Falls.
"In the past three years, active license agreements have climbed from a couple of dozen to more than 70 licenses with universities, governments and corporations worldwide," said Gary Smith, senior commercialization manager for Nuclear Science and Technology. "In FY 2013, RELAP licensing income exceeded $\$ 680,000$ and a large majority of this royalty income was used for further development of the code."

INL copyright fee-bearing licensing activity in FY2013 nearly doubled those signed in 2008 and accounted for 66 percent of INL licensing during the past five years. RELAP has led the way in increased license activity, but newly developed software inventions during that period have grown rapidly. These new products with interesting names and purposes include PHISICS, MOOSE, and Sophia, whose licensing activity is detailed in this report.

More digital copyright licensing is anticipated during the next several years. INL is embracing 'open-source software' (OSS) licensing to deploy INL innovations. OSS offers many potential advantages, including enhanced collaborative opportunities, a variety of perspectives on task innovation, and maximum exposure for INL developers.

"Achieving greater use and distribution of INL-developed software substantiates the public's investment in federal research and leads to long-term viability of the laboratory," said Steve McMaster, director of Technology Deployment.

FY2013 was an extremely productive year executing about a hundred fee-bearing and non-fee-bearing licenses. The following provides a short summary of that activity.

\section{Sophia SCADA Network Fingerprinting Tool (Sophia): Non-Commercial License Agreements}

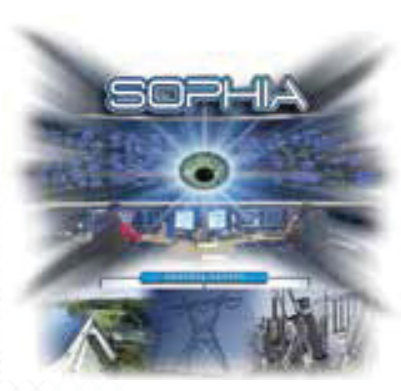

INL signed 27 beta testing, commercialization evaluation and government use licenses during FY2013. Sophia was funded from the DOE's Office of Electricity Delivery and Energy Reliability and is a passive, real time tool for inter-device communication discovery and monitoring of the active elements in a Supervisory Control and Data Acquisition (SCADA) system.

Licenses for FY2013 include:

- Princeton Plasma Physics Laboratory

- Naval Surface Warfare Center Carderock - Philadelphia

- SLAC National Accelerator Center

- Lower Colorado River Authority

- DTE Energy - MichCon

- Vertech

- Emergent BioDefense

- Colonial Pipeline Company
- Garland Power \& Light

- Joel T. Langill

- Luminant Energy

- PPG Industries, Inc.

- Great River Energy

- Union Sanitary District

- West Palm Beach, FL Water Department

- Nuclear Regulatory Commission

- U.S. Cyber Command

- Dept. of Homeland Security, Industrial control Systems Cyber Emergency Response

- Dept. of Army - Southwest Asia Cyber Center

- Oak Ridge National Laboratory

- Power Fingerprinting, Inc.

- Red Tiger Security, LLC

- National Informaton Solutions Cooperative

- Firmitas, LLC

- Tenable Network Security, Inc.

- Critical Intelligence, Inc.

- NexDefense, Inc. 


\section{RELAP5-3D Licensing Continues to Grow}

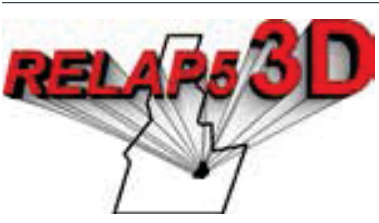

For decades, Reactor Excursion and Leak Analysis Program (RELAP) has been widely used by the international nuclear community to support research and nuclear studies, including safety analysis and evaluation of innovative ideas. INL, in cooperation with the International RELAP Users Group (IRUG), has developed the latest in the RELAP5-3D code series to analyze transients and accidents in water-cooled nuclear power plants and related systems. Known within the nuclear community for its fully integrated, multi-dimensional thermal-hydraulic and kinetic modeling capability, RELAP5-3D now is being used by other industries to conduct systems analyses on steam supply systems and jet engine performance.

During FY2013, 72 licenses for RELAP5-3D were active, including 35 new licenses (listed below) and 15 more modified during that time.

- Institute of Nuclear Safety System

- Texas A\&M University

- NuScale Power, LLC

- University of Zagreb

- GSE Power Systems, Inc.

- Arizona Public Service

- Aerospace Systems Directorate

- Ansaldo Nucleare SpA

- University of Illinois

- Nucleoelectrica Argentina S.A. - Unidad de Gestion Central Nuclear

- Karlsruher Institut fur Technologies

- Industrial Leak Detection, Inc.

- Atomic Energy Licensing Board

- University of Pittsburgh

- Mitsubishi Nuclear Energy Systems, Inc., Japan

- Oceanit Laboratories, Inc.

- Rolls-Royce Power Engineering plc

- Electric Boat Corporation

- Sandia National Laboratories

- Applied Programming Technology, Inc.

- AREVA NP Inc.

- Incorporated Administrative Agency, Japan Nuclear Energy Safety Organization

- University of Rome "La Sapienza"

- UJV Rez a.s.

- University of Idaho

- University of Pisa

- MVM Paks II, Nuclear Power Plant Development Private Company
- Oak Ridge National Laboratory

- Energy, Safety and Risk Consultants

- TechFlow, Inc.

- Dept. of Nuclear Safety, Taiwan Power Company

- Brookhaven Science Associates, LLC

- X-Energy, Inc.

- University of Missouri - Nuclear Research Reactor

- N.A. Dollezhal Research and Development Institute

MOOSE Licenses Advance INL's Nuclear Mission: Makes INL Software Available to Industry, Academia, and National Laboratories

INL signed 19 multi-year, non-exclusive licenses for INL's Multiphysics Object Oriented Simulation Environment (MOOSE) software during FY2013. Designed as a framework for the development of complex multi-dimensional engineering analysis applications using the finite

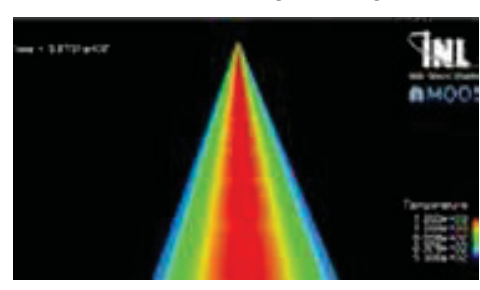
element method, MOOSE provides a clean, extensible interface for scientists to develop analysis applications by accepting weak forms for the mathematical models that govern the behavior of the physical system being modeled. This software was created using funding from INL's Laboratory Directed Research and Development (LDRD) and in FY2013 has been licensed to:

- University of South Carolina

- Commonwealth Scientific and Industrial Research Organisation

- University of Wyoming

- Idaho State University

- The University of Western Australia

- Texas Engineering Experiment Station

- National Security Technologies

- University of Florida

- GSE Power Systems, Inc.

- University of Illinois

- Ohio State University

- Duke University

- The Regents of the University of California

- Washington State University

- University of Connecticut

- TechFlow, Inc.

- Royal Military College of Canada

- Georgia Institute of Technology

- GE Global Research 


\section{PHISICS Software Licensing Growing}

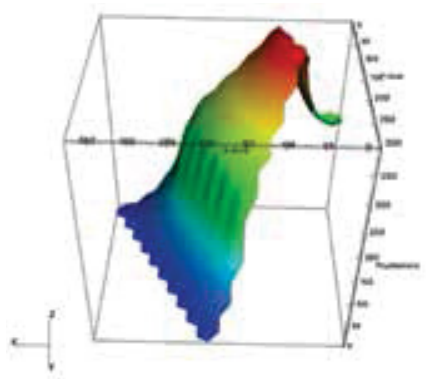

Parallel and Highly Innovative Simulation for INL Code System, called PHISICS, is a software package intended to provide a modern analysis tool for reactor physics investigation. PHISICS is designed to maximize accuracy for a given availability of computational resources. This is achieved by using several algorithms and meshing options to optimize computational resources and desired accuracy levels. INL was granted copyright assertion by DOE in 2012.

PHISICS is available to users as a stand-alone version or coupled with RELAP5-3D precompiled libraries. It can be compiled on MAC, LINUX, and Windows, which makes it more flexible and portable than competing software packages. PHISICS also is modular in structure, which facilitates simple and independent modification to its various algorithms, enabling rapid implementation of new calculation schemes.

TD is currently licensing PHISICS on a non-exclusive basis for further development and validation. Licensees during FY2013 include:

- Politencnico Di Milano - Department of Energy, CeSNEF Nuclear

- University of Bologna, DIENCA Department, Montecuccolino Laboratory

- University of Illinois, Urbana-Champaign, Illinois

- Tech-X Corporation, Boulder, CO

- North Carolina State University

- ENEA Italian National Agency for New Technologies, Energy \& Sustainable Economic

\section{North Carolina State University: Executes a License Agreement to Deploy MarmotViz Software}

\section{NC STATE UNIVERSITY}

The first license deploying the MarmotViz software was executed with North Carolina

(NC) State University in August. MarmotViz is an illustrative visualization plug-in for ParaView. It enables users to identify and track timevarying features in simulation datasets. The tool assists in exploration and interpretation of simulation data and can be used to generate enhanced renderings for presentation. The NC State College of Engineering will make use of MarmotViz in various projects.

Thermochem Recovery International, Inc.: License for INL's Aspen plus Coal-to-Liquids Model

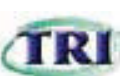

Thermochem Recovery international, Inc.

This license agreement grants TRI nonexclusive rights to make use of BEA adapted Aspen Plus models in order to support the further development of TRI's coal-to-liquids conversion processes. The models were previously adapted under a work for other (WFO) agreement with TRI. 


\section{Royalties}

Royalties have reached more than $\$ 11$ million during the past nine years at INL, varying each year from about $\$ 800,000$ in fiscal year 2005 to more than $\$ 1.6$ million in fiscal year 2009. Earning more than $\$ 1.55$ million in royalties this past year, FY2013 ranked among the highest royalty producing years for INL. The stable and significant annual royalty income reflects an expanding portfolio of intellectual property. It also means there is increased attention to commercialization of these discoveries and inventions.

During FY 2013, U.S. businesses marketed more than $\$ 50$ million in innovative products and processes based on INL patented technology. As a result, utilization of INL technology in the market place has resulted in job creation and increased U.S. global competitiveness.

Commercial markets have been very accepting of INL-developed technologies. From FY2005 to FY2013, INL has signed more than 838 licenses for commercialization of technologies developed within the laboratory and 126 licenses being executed in FY2013.

This success comes from excellent research and strong laboratory support based on strategies that provide needed investments where they are needed most. Investments have been made with the income from licensing activities and focused on funding more mission-related research and development, plus recognition and reward for laboratory employees who are contributing significantly to the transfer and commercialization of INL technologies. Other investments are made based on value related to the research and development mission and those activities that could significantly increase the licensing potential of INL technologies.

INL's Innovation Development Fund and Science and Technology Strategic Investment Opportunities are two Royalty mechanisms that are used for these reinvestment strategies and have advanced the transfer of laboratory-developed technologies to nonfederal parties as required by technology transfer legislation. These projects have permitted development of stronger relationships to various markets, yielding exceptional return on investment to the U.S. public from INL research. Focusing on commercial results has helped create success.

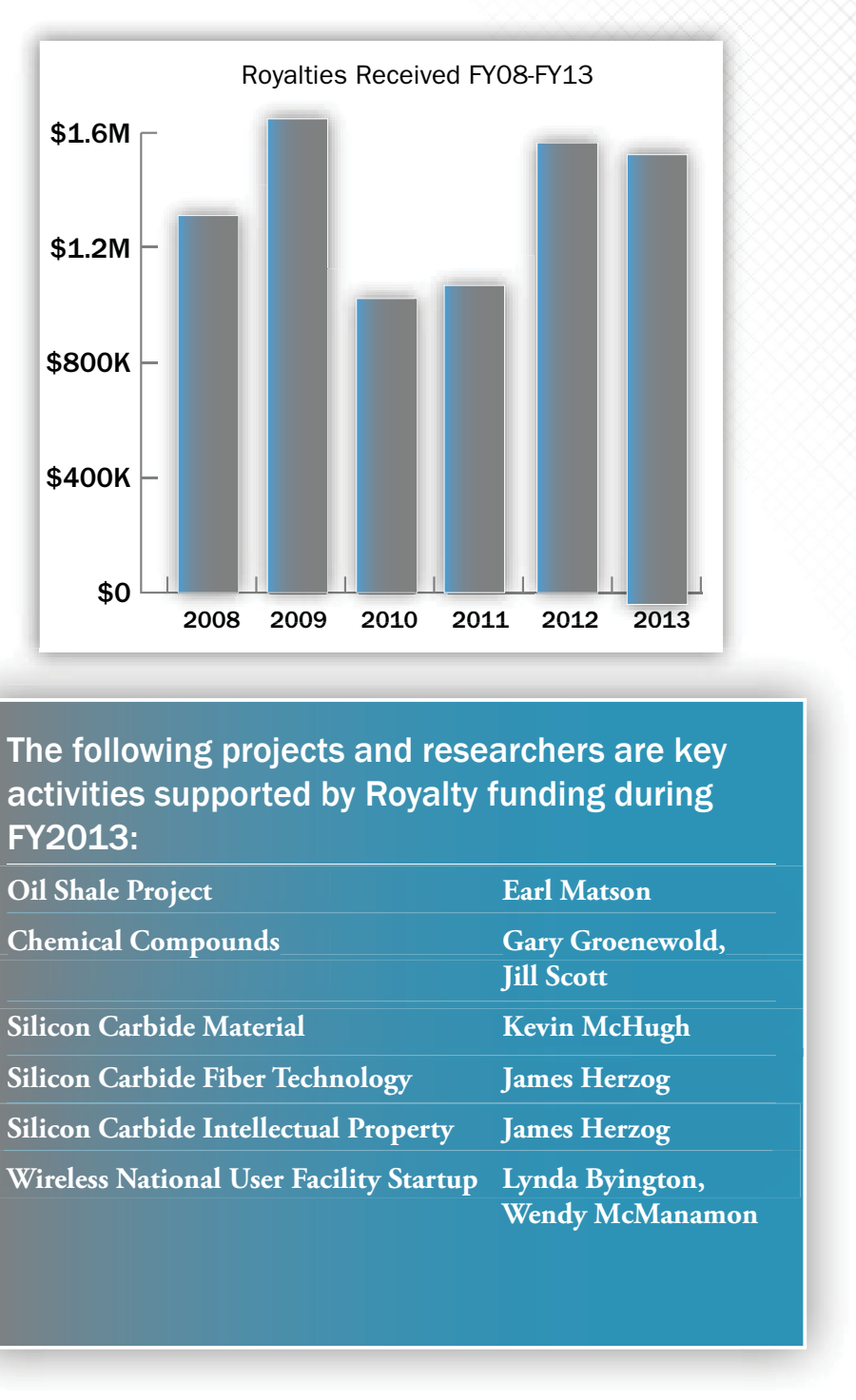




\section{Cooperative Research and Development Agreement Highlights}

During the past nine years, INL's successful Cooperative Research and Development Agreement (CRADA) program has signed 132 new CRADAs representing nearly $\$ 300$ million of research work. Fifteen new CRADAs were signed during FY 2013 and 21 modifications to existing CRADAs were executed. The total CRADA value during the year was more than $\$ 51$ million, including about $\$ 31.5$ million of funds-in, $\$ 7.3$ million of in-kind contributions from participants, and about $\$ 12.3$ million in government contributions.

CRADAs may be for short periods of time or may extend several years depending on the objectives of the collaboration. The number of transactions and the corresponding resource commitments vary considerably from year to year based on the technologies available at INL, the readiness of participants to invest in collaborations, and INL's ability to identify the right participants and negotiate satisfactory business relationships.

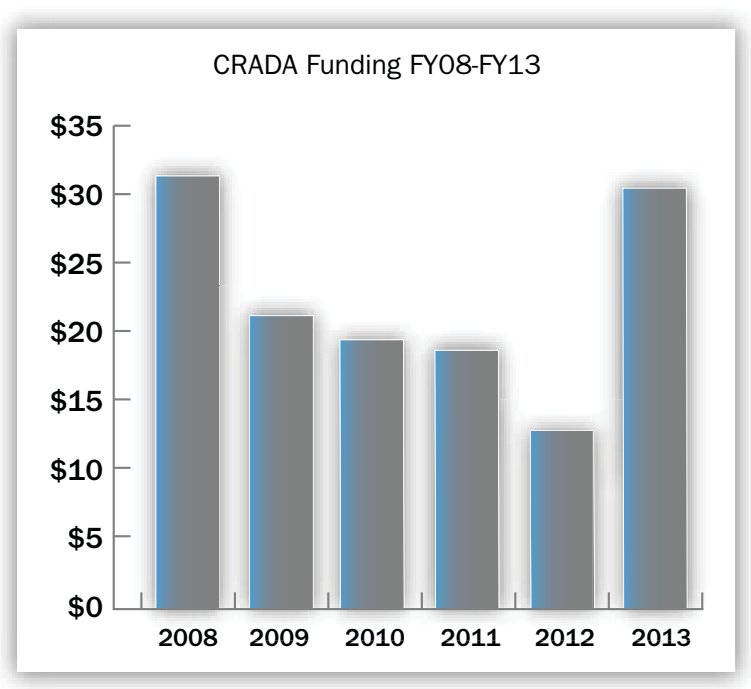

CRADAs for FY2013 are listed below, followed by a summary of selected agreements.

\begin{tabular}{|c|c|}
\hline CRADA Participants & Technology \\
\hline Alstom & Vulnerability Assessment of Industrial Control Systems \\
\hline Bridgeway Capital Advisors, Inc. & Biomass Comminution Study using new DOE designated feedstock national user facility at INL \\
\hline $\begin{array}{l}\text { Schneider Electric, U.S. } \\
\text { (previously Televent USA, Inc.) }\end{array}$ & Vulnerability Assessment of Industrial Control Systems \\
\hline Ceramatec, Inc. & Evaluate Materials for Solar Energy Application \\
\hline ECOtality North America & Vulnerability assessment of EVSE supply system \\
\hline TerraPower, LLC & Fuel Fabrication and Test Pin Fabrication Development \\
\hline TerraPower, LLC & Support TerraPower Fast Spectrum Fuels Tests \\
\hline General Electric Global Research & Global umbrella cooperative research agreement \\
\hline Honeywell International, Inc. & Review Honeywell's Experion Industrial Control Systems \\
\hline Dairy Research Institute & Analyze integrated model for operations, energy and environment \\
\hline $\begin{array}{l}\text { Electric Power Research } \\
\text { Institute (EPRI) }\end{array}$ & Post Irradiation Examination of alloys X-750 and XM-19 \\
\hline $\begin{array}{l}\text { Korea Atomic Energy Research } \\
\text { Institute (KAERI) }\end{array}$ & Test Cyber Security Industrial Control Systems \\
\hline $\begin{array}{l}\text { Korea Atomic Energy Research } \\
\text { Institute (KAERI) }\end{array}$ & Perform conceptual design for lead reactor test assembly \\
\hline Chevron Energy Technology Co. & Switchable Polarity Solvent Forward Osmosis \\
\hline
\end{tabular}




\section{Chevron Energy Technology Company: Executes CRADA for Research with SPS FO}

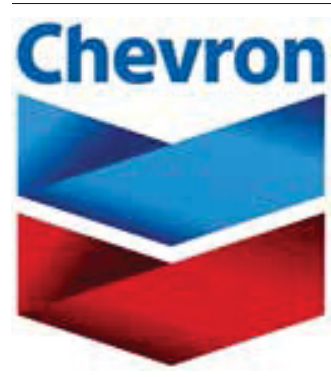

Chevron Energy Technology Company signed an agreement to collaborate on developing Switchable Polarity Solvent Forward Osmosis (SPS-FO) for low-cost water purification. By selecting specialized thermolytic salts, the SPS-FO process can purify water from extremely concentrated feeds containing components such as salts, organics, inorganics and biologics. SPS-FO can reduce the volume of a feed solution concentrating it to near dryness thereby reducing waste. The SPS-FO process also can be used to facilitate manufacture of salt brines for fossil fuel extraction and solution mining, isolation of aqueous products from microbial synthesis, and re-concentration of diluted reagents for reuse.

Bridgeway Capital Advisors, Inc. and Forest Concepts, LLC:

\section{Execute Agreement for Study of Biomass Feedstock}

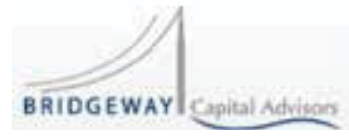

Bridgeway Capital and Forest Concepts signed an agreement to collaborate with INL in using DOE's designated Biomass Feedstock National User Facility. Activities will include use of INL's Process Demonstration Unit (PDU) to compare energy consumption and resulting particle properties at pilot scale for three methods of biomass comminution (grinding) - hammer mill (INL PDU), Forest Concepts' Crumbler rotary shear, and Vortex Processing's collision mill.

This study will conduct a comparison of three comminution technologies with consistency in materials and methods to inform biomass pre-processing designs. The work will integrate equipment from Forest Concepts and Vortex Processing into the Biomass Feedstock National User Facility (BFNUF PDU) at INL, and then process sufficient quantities of same corn stover, switchgrass and wood chip material to make a quantitative analysis of energy consumption and particle size reduction performance and efficiency. A report will be developed containing a quantitative analysis of the performance of the three technologies.

\section{GE Global Research:}

\section{Signs Umbrella CRADA for Broad-Range of Research}

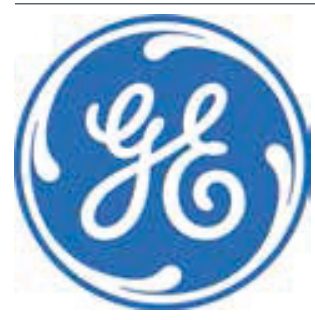

This agreement anticipates a series of collaborative research projects with GE Global Research and will facilitate teaming arrangements in response to federal agency requests for proposals. Focus areas to be considered under this agreement include aero-thermal mechanical systems, chemistry and chemical engineering, diagnostics and biomedical imag ing, diagnostics and biomedical technologies, Edison Engineering Development Program, electrical technologies and systems, manufacturing and materials technologies, and software sciences and analytics.
ALSTOM Grid, Inc.: Signs for Vulnerability Assessment Project by National SCADA Test Bed at INL ALSTOM

ALSTOM Grid signed an agreement to participate in the National SCADA Test Bed Program at INL to evaluate vulnerabilities and mitigation strategies for the company's Pipeline Control System Software e-terra, which supports safety pipeline infrastructure. The company responds to the needs of oil and gas network operators for supervisory control, assets security monitoring, odelling and simulation tools, and other key pipeline operations.

Telvent USA, LLC (now Schneider Electric, U.S.): Signs Vulnerability Assessment for the Telvent Distribution Management System (DMS)

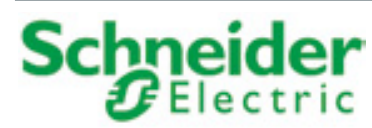

Schneider Electric, U.S. signed an agreement to conduct a vulnerability assessment for Telvent DMS, Advanced Distribution Management System (ADMS). This system provides a comprehensive network management solution for electric distribution networks. By merging DMS, outage management system (OMS), and supervisory control and data acquisition (SCADA) systems into one secure, unified solution with more ethan 50 advanced functions, it can maximize benefits from a growing abundance of intelligent grid devices, distributed renewable energy, advanced metering, and all things smart grid. Telvent USA, LLC, now Schneider, is a global company that provides industrial control systems solutions and information services to improve the efficiency, safety, and security of the world's leading companies.

Electric Power Research Institute, Inc. (EPRI): Evaluate Alloys $X-750$ and $X M-19$

\section{$=\rightleftharpoons \mid \begin{aligned} & \text { EleCtric pOWER } \\ & \text { ReSEARCH INSTITUTE }\end{aligned}$}

This research will provide quantitative data on crack growth rates and fracture toughness of irradi-

ate alloys X-750 and XM-19. The project will include both irradiation of the subject materials at INL's advanced Test Reactor and analysis at INL's Materials Fuels Complex.

Progress Energy (dba Duke Energy): Modifies agreement expanding current work

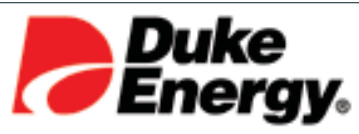

Duke Energy expanded the original

Human Factors Engineering service to include "Review Operating Experience", "Review NRC Plant Licensing Basis",

"Functional Analysis and Functional Allocation", and "Task Analysis and Operational Sequence Analysis" at the H.B. Robinson nuclear operating plant near Hartsville, SC in anticipation of the utility replacing its Plant Process Computers. 
Honeywell International, Inc.: Agrees to Vulnerability Assessment by National SCADA Test Bed at INL

\section{Honeywell \\ Honeywell International, Inc. signed an agreement for a collaborative partnership with INL to perform vulnerability assess- ments of Honeywell's security control systems. Honeywell Laboratories was awarded a research project titled "RBAC Driven Least Privileged Architecture for Control Systems" by the Department of Energy (DOE) Office of Electricity Delivery and Energy Reliability, Research and Devel- opment Division, Cyber Security for Energy Delivery Systems Program, which is managed through the National Energy Technology Laboratory (DOE-NETL). The INL will lead the demonstration of the research by validation through the INL's SCADA Test Bed.}

TerraPower, LLC:

\section{Signs two CRADA Agreements - Fuel Fabrication} Testing, Fast Spectrum Fuel Tests

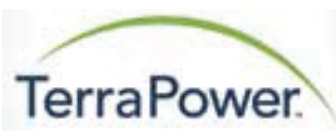

To advance their traveling wave reactor design, TerraPower, LLC signed two CRADAs for fuel fabrication and testing. One agreement is to jointly develop fuel fabrication at INL's Experimental Fuel Facility and Fuels Applied Science Building. The second agreement supports TerraPower's fuel pin irradiation test program for their traveling wave reactor design. Analysis includes metallic fuel irradiation behavior, fuel fabrication, post irradiation and fast reactor structural materials. Additional agreements are to be signed in FY2014 and will expand the cooperation between TerraPower and INL.

ECOtality North America: Signs Agreement for a Vulnerability Assessment

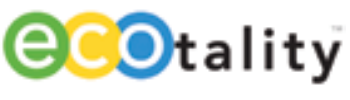

ECOtality (Electric Transportation Engineering Corporation dba ECOtality North America) has contracted for a new vulnerability assessment to determine the susceptibilities and recommend mitigation strategies for the ECOtality Electric Vehicle Supply Equipment (EVSE) system. The company seeks to enhance its industry control system protection and the emerging electric vehicle infrastructure.

\section{Work for Others Highlights}

INL's Work for Others (WFO) program allows other agencies and the private sector to leverage INL capabilities and intellectual knowledge on a full cost recovery basis. Since 2005, WFO has contracted for 376 new projects that represent nearly $\$ 1.3$ billion of work.

In FY2013, due in large part to the federal budget remaining under continuing resolution and the impact of sequestration, only three new federal WFO projects were executed. However, there was work being done for a number of federal agencies as evidenced by more than 300 agreement modifications. The private sector WFO agreements included 26 new projects (13 for EEST, 11 for NST, 2 for NHS) with another 37 modified, the value of those 63 agreements will exceed 4.9 million. Since 2002, non-federal WFO agreements have been responsible for more than $\$ 50$ million in funding at the INL. The total WFO value during FY2013 is about $\$ 107$ million.

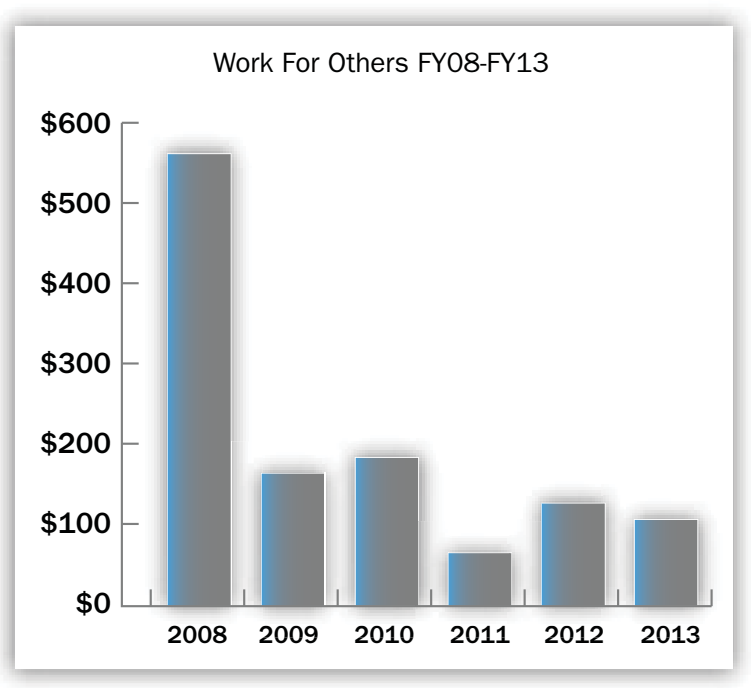


Some of INL's significant WFO projects include:

International Isotopes Inc. (INIS):

Signs Two WFO Agreements -

Evaluate Cobalt Targets, Establish Capability to Use Cobalt-60 Shipping Containers

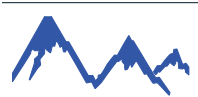

INIS has signed two contracts regarding Cobalt- 60 production and International Isotopes Inc. shipping. INL will evaluate INIS documention of Cobalt-60 targets, analyze target quality and identify any corrective actions. To facilitate movement of Cobalt-60 targets, INL will assist in re-establishing capability to use INIS-2 shipping containers.

\section{AMEC Nuclear UK Limited:}

Signs Agreement to use the MELCOR Code

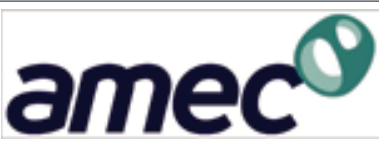

INL has been contracted to use the MELCOR code, modified under the INL Fusion Safety Program, to develop a model of the European Union's International Thermonuclear Experimental Reactor (ITER), European Helium Cooled Lithium Lead prototypical fusion reactor Test Blanket Module (TBM) concept.

Hitachi Power Systems America, Ltd.: Contracts Technical Support Gained from TMI Accident

HITACHI Inspire the Next
INL is leveraging analytical expertise developed in the aftermath of the Three Mile Island accident on March 28, 1979 in Harrisburg, PA. INL will provide support on technical issues related to the sampling and characterization of the Fukushima Daiichi Nuclear Power Plant, Fukushima Prefecture, Japan, (Fukushima) damaged on March 11, 2011. Specifically, work will include development of waste storage containers for the removed waste, sharing information from the TMI accident, and conducting technical reviews of Hitachi plans for characterization of the Fukushima facilities, including removal of the fuel from the reactor core and the requirements for waste containers.
Boise State University (BSU): Signs Two Contracts - Research Web-Based Decision Tool for Use in Greenhouse Gas Production at Dairy Farms, Support Management of MaCS

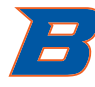

Boise State University signed two contracts with INL. The first is for assistance BOISE STATE UNIVERSITY in developing and deploying web-based management decision tools for dairy farms, which integrate greenhouse gas reduction, carbon-sequestration and anaerobic digester (AD) modeling capabilities. The web-based model, Decision-Support for Digester-Algae IntegRation for Improved Environmental and Economic Sustainability (DAIRIEES), assists in decision-making and education by considering environmental and economic effects of implementing an integrated AD-algal system.

Also, BSU through the Center for Advanced Energy Studies (CAES) has requested INL assistance in managing the the Microscopy and Characterization Suite $(\mathrm{MaCS})$, a state-of-the-art materials characterization laboratory. MaCS capabilities provide key support for the Center for Advanced Energy Studies (CAES) mission in multiple initiative areas and complements the BSU's Center for Materials Characterization.

ThermoChem Recovery International, Inc. (TRI): Executes Agreement to Adapt INL Aspen Models

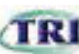

TRI has contracted support from INL to adapt Aspen Plus models for use in simulating TRI's coal/biomass to

liquids gasifier process. The gasifier models to be adapted were developed at the INL. INL also will provide TRI with the training necessary to perform further adaptations of the model as necessary.

GE Global Research:

Executes Agreement to Evaluate Liquefied Natural Gas Post Liquefaction CO2 Removal Technologies

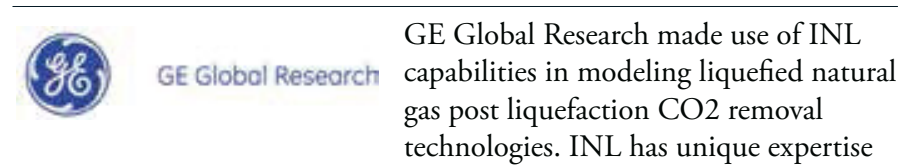

in this area resulting from the previous development of a natural gas liquefaction process demonstrated by INL researchers. The objective of this work is to evaluate the technical barriers of post liquefaction clean-up as an alternative to conventional methodologies. 
Physical Optics Corporation: Signs Agreement for Non-Destructive Examination System for Nuclear Graphite Components

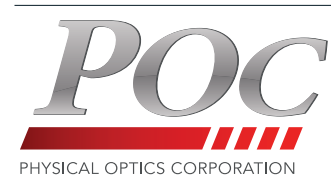

Physical Optics Corporation (POC) was awarded Phase 1 Small Business Invention Research funding to develop an X-ray back scatter inspection technology to support inspection of high temperature gas reactor graphite materials. INL will support this effort by providing guidance on likely inspection requirements/specifications, as well as provide nuclear grade graphite materials to allow POC to test the capabilities of their system.

\section{Southern Research Institute (SRI): Contracts Research on Carbon-Carbon Materials}

\begin{tabular}{|c|c|}
\hline $\begin{array}{l}\text { SOUTHERN RESEARCH } \\
\text { INSTITUTE }\end{array}$ & $\begin{array}{l}\text { SRI has contracted support to perform } \\
\text { research tasks, including measuring the } \\
\text { oxidation rate of selected carbon-carbon } \\
\text { materials and a graphite standard under } \\
\text { controlled conditions for comparison of }\end{array}$ \\
\hline \multicolumn{2}{|c|}{$\begin{array}{l}\text { performance. The quantification of oxidation kinetics for high-strength, } \\
\text { carbon-based materials, such as carbon-carbons, is essential for achieving } \\
\text { accurate predictions of hypersonic vehicle flight, especially in the upper } \\
\text { atmosphere. }\end{array}$} \\
\hline
\end{tabular}

NuScale Power, LLC.:

Contracts for Technical/Economic Assessment of NuScale Hybrid Energy Applications

NUSCALE NuScale has contracted with INL for a POWER technical and economic assessment (TEA) for hybrid energy applications. The purpose of this effort is to assess technical and market viability considerations for integrating a NuScale palnt into specific hybrid energy configurations.

\section{Emery Energy, LLC:}

\section{Signs Biomass-Syngas Testing Agreement}

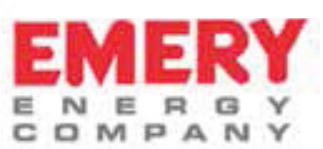

Emery Energy Company, LLC signed an agreement for on-site testing and monitoring of an updated syngas reforming demonstration unit at their biomass plant in Laramie, WY. INL completed testing and monitor-

ing during the development and initial demonstration of this facility in 2012. Successful testing at the Emery plant will provide an improved process for converting biomass to liquid fuels and/or energy.

\section{Ceramic Cement Corporation:}

\section{Signs a Contract for Ceramic Cement Testing}

Ceramic Cement Corporation signed a contract for INL to perform gamma and neutron testing of the company's shielding materials, along with Nuclear Regulatory Commission (NRC) Branch Technical Waste Form Testing. The tests will document the quality of the ceramic cement based waste form for approval by state regulatory agencies for disposal uses.

\section{Canadian Nuclear Safety Commission: Executes Agreement for Training Courses}

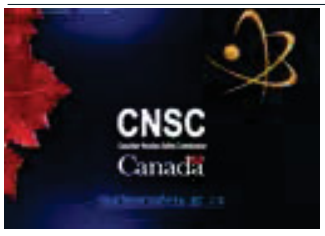

INL will present two Probabilistic Risk Assessment (PRA) methodology based training courses for the Canadian Nuclear Safety Commission (CNSC) in Ottawa, Canada. The PRA training courses are the U.S. Nuclear Regulatory Commission's (NRC) External Events (P-204) course and the Accident Progression Analysis (P-300) course.

Sulphur Springs Valley Electric Cooperative (SSVEC): Signs Agreement for Radio Frequency Propagation Study

Sulphur Springs Valley SSVEC has been funded to deploy the Electric Cooperative, Ine communications infrastructure for Distribution Automation, a Smart Grid Investment Grant (SGIG) project. SSVEC has contracted with INL to conduct a propagation study in the spectrum in which mobile WiMAX transmitters and endpoints operate. The region to be studied is in and around Sierra Vista, Arizona.

Science Applications International Corporation (SAIC): Contracts for Nuclear and Radiological Imaging Platform (NRIP) Program Concept of Operations

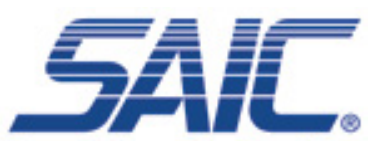

SAIC signed an agreement for INL to provide assistance in developing a concept of operations for the Nuclear and Radiological Imaging Platform (NRIP) From Science to Solutions Program. INL will conduct experiments, modeling, analysis and trade studies for Phase I, which will culminate in a Preliminary Design Review (PDR) and report to SAIC's customer, the Domestic Nuclear Detection Office (DNDO). 
Battelle Memorial Institute (BMI):

Signs Agreement for Characterization and Decontamination of Surfaces, Structures, and Soils

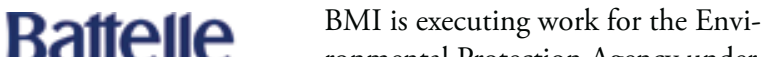 ronmental Protection Agency under a}

The Business of Innovation multi-year program and has contracted with INL for tasks that address characterization and decontamination of surfaces, structures, soils, and other media. INL will focus on acute contamination events from intentional, accidental, or natural disasters.

\section{Safety and Ecology Corporation:}

Executed contract for a Byproduct Utilization Program 500-Watt Radioisotopes Thermoelectric Generator

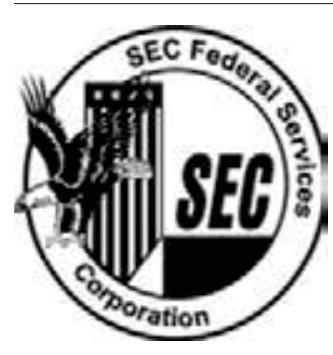

This work agreement has INL conducting a research assessment to evaluate the use of a Byproduct Utilization Program 500-Watt (BUP-500) Radioisotope Thermoelectric Generator (RTG), located at the Oak Ridge National Laboratory. Safety and Ecology Corporation, through SEC Federal Services, a Contractor to ORNL, is evaluating the equipment, personnel, and system documentation for the RTG's capability to power monitoring equipment at the Nevada National Security Site (NNSS).

Ontario Power Generation (OPG): Executes Agreement for Updates to IWTS

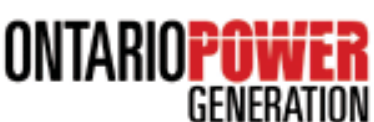

OPG signed an agreement to obtain update support for INL's Integrated Waste Tracking System (IWTS) software, which integrates, stores, tracks, and provides access to large amounts of waste inventory and characterization data. OPG has used IWTS for more than seven years.

Materials and Systems Research, Inc.: Contracts Development of Electrolysis Cell Systems for Space Exploration

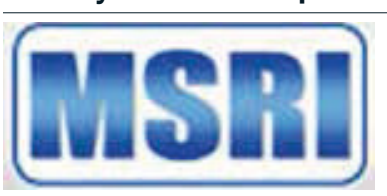

MSRI of Salt Lake City contracted high temperature electrolysis testing at elevated pressures to support the development of solid-oxide electrolysis cell systems used to supply fuel and oxygen on various space exploration missions. MSRI's work is part of NASA research efforts.
X-Energy, LLC:

Signs for Feasibility Study of Nuclear Power Plant Design

$\mathrm{X}$-Energy, LLC signed an agreement for INL to review and evaluate the feasibility of X-Energy's conceptual nuclear power plant design.

\section{U.S. Environmental Protection Agency:} Executes Agreement to Build Water Security Test Bed

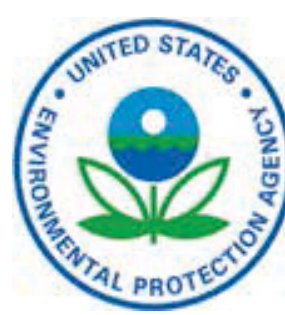

The work scope for the first phase of the Water Security Test Bed (WSTB) project includes the design and installation of an above-ground piped water system at the INL Power Burst Facility/Critical Infrastructure Test Range Complex area. Elements of a public water distribution system will be represented in this design. Once the WSTB is in place, future work scope will be defined with the Environmental Protection Agency to use the system for evaluation of contamination detection and water system decontamination technologies.

\section{U.S. Army Edgewood Chemical Biological Center (ECBC):}

Executes Agreement for Portable Isotopic Neutron Spectroscopy (PINS) and Digital Radiography and Computed Tomography (DRCT) Training

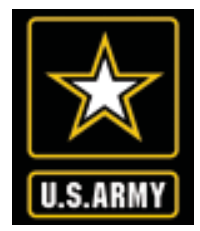

ECBC requires training on the PINS and DRCT systems developed at INL for use in future overseas missions to assess suspect chemical warfare munitions. The training scope includes classroom training, hands on operation, basic maintenance and tear down of the systems for shipping.

\section{Space and Naval Warfare}

\section{Systems Command (SPAWAR):}

Signs Agreement for Unmanned Aerial System Communications

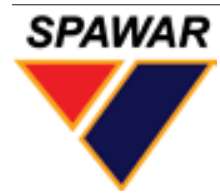

SPAWAR, which delivers high-end information technology products and services for the Department of Defense, requested assistance in designing, developing and deploying a Common Data Link (CDL) terminal for use by small unmanned aerial systems in intelligence, surveillance, and reconnaissance data collection. 


\section{Technology-Based Economic Development Highlights}

\section{Nurturing Economic Development}

INL has designed its Technology Based Economic Development (TBED) program to build, connect and inspire economic activity with creative people like researchers, entrepreneurs, technologists, economic development professionals, scientists, engineers, educators and college students. Activities range from business introductions to gaining access to INL researchers, technical expertise, and capabilities. Altogether, the three-fold mission is to help create economic growth.

\section{Build}

\section{Access to INL's Capabilities, Technical Expertise}

INL's Technical Assistance Program (TAP) is a federally-mandated program authorizing INL to share knowledge and specialized equipment to promote U.S. competitiveness. Through TAP, INL scientists and engineers can provide limited, free assistance that is not commercially available in the region to benefit a community or small business. During the past nine years, INL has dedicated more than 8,140 hours to TAP projects. Select projects for 2013 include:

- A small business conference on available cyber security resources helped reduce vulnerability.

- A subsurface investigation using geophysical survey equipment intended to support criminal forensic searches for law enforcement.

- Fabrication expertise provided specialty glass ware for a chemical engineering experiment.

- Analysis of data and geophysical locations for proposed landfill expansion aided decision making relative to Holcene faults and seismic impact zones.

\section{A Cohesive Statewide Economic Development Strategy} University of Idaho TBED contributed \$3,000 in sup-
port of the University of Idaho (U of I), which is leading the Idaho Pathways Project- Statewide Comprehensive Economic Development Strategy to develop a regional plan for economic development. Organized by U of I's Gene Merrell, Associate Vice President for Economic Development, the project involves the six economic development districts and five state agencies - Commerce, Labor, Transportation, Agriculture, and Environmental Quality. Seeking to employ data-driven strategies, the project has two educational components that involve three $\mathrm{U}$ of I graduate students and regional working groups.

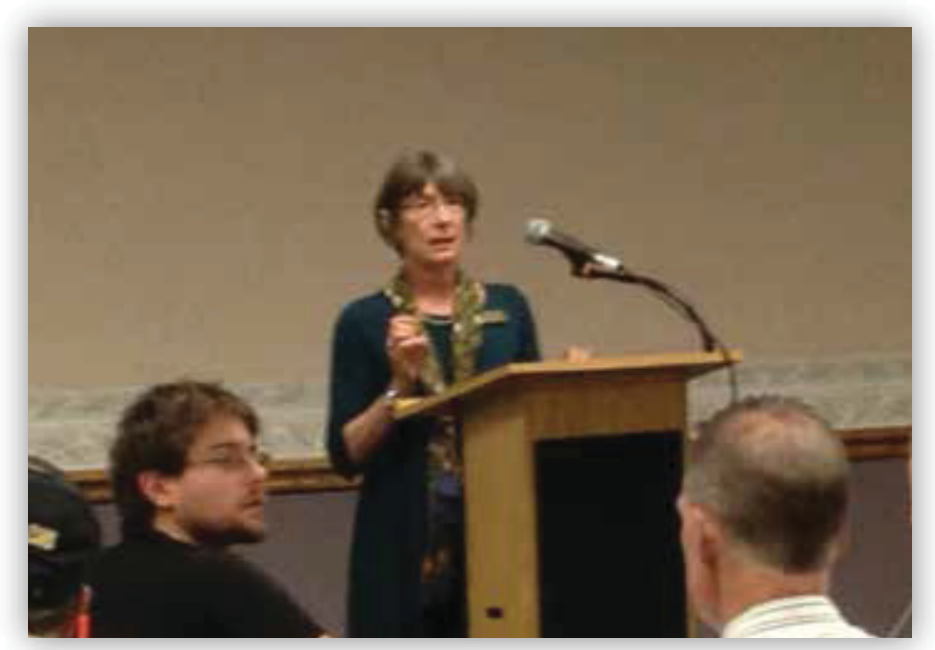

Priscilla Salant from the University of Idaho speaks to the Community Stewardship for Economic Benefits Symposium in Twin Falls, Idaho during March 2013.

\section{A Friendlier Environmental Footprint}

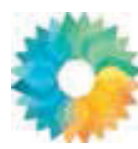

\section{Community Stewardship for Economic Benefits}

The Community Stewardship for Economic Benefits Symposium addressed critical issues, including sustainable wastewater treatment, efforts to shrink landfills and environmentally friendly solid waste treatment practices during a March conference. More than 160 participants representing 27 Idaho communities attended the event in Coeur d' Alene and Twin Falls using an INL-sponsored video link and rural scholarships for attendees, speakers and planning committee support. The University of Idaho's Office of Community Partnerships coordinated the two-campus event that connected North Idaho College and College of Southern Idaho during the two-day event. New technologies and innovations were showcased in a special 'ignite presentation format' that included speakers from public agencies, private engineering firms, communities and universities.

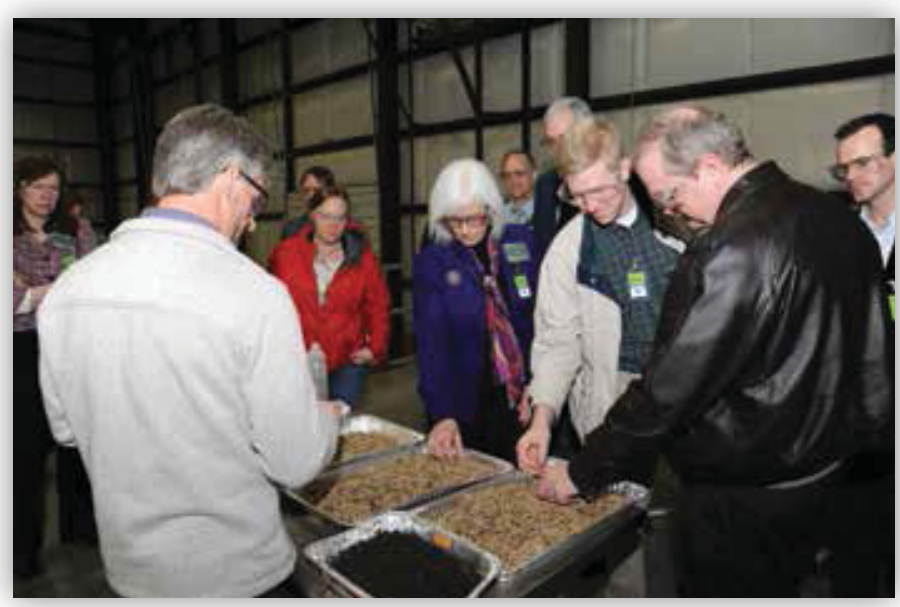

INL biofuels and renewable energy researcher Kevin Kenney displays biofeedstock pellets during a group tour of the new Energy Systems Laboratory. 


\section{Connect}

\section{Energy Connected Conference}

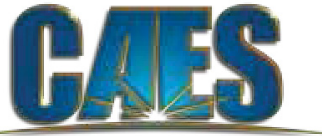
Energy Studies
Center for fiduanced

Innovation is a team sport. In February 2013, a team of more than 60 people from industry, universities and the investor community convened to learn about INL and CAES resources and capabilities at the Energy Connected Conference.

During a two-day conference, they learned about hybrid energy systems, advanced transportation systems, environmental management, and advanced computational modeling.

INL's Steve McMaster led a panel discussion on technology transfer opportunities that included Gene Merrell of the University of Idaho, Darlene Gerry from Idaho State University and Mary Andrews of Boise State University. The group toured INL's new 91,000-square-foot, LEED-certified Energy Systems Laboratory (ESL), where they learned about bioenergy, hybrid energy and advanced vehicle research conducted in the facility. TBED provided speakers and planning committee support for the conference.

\section{Rural Idaho to Broadband}

A statewide initiative to promote broadband expansion and adoption throughout Idaho, LinkIDAHO promotes regional collaboration and coordination in social and economic areas, including healthcare, education, libraries and economic development. In Aug. 2013, LinkIDAHO launched a mobile broadband test to map coverage areas and identify gaps found primarily in rural Idaho. TBED has promoted LinkIDAHO and its efforts to develop mobile broadband in rural Idaho for more than a year.

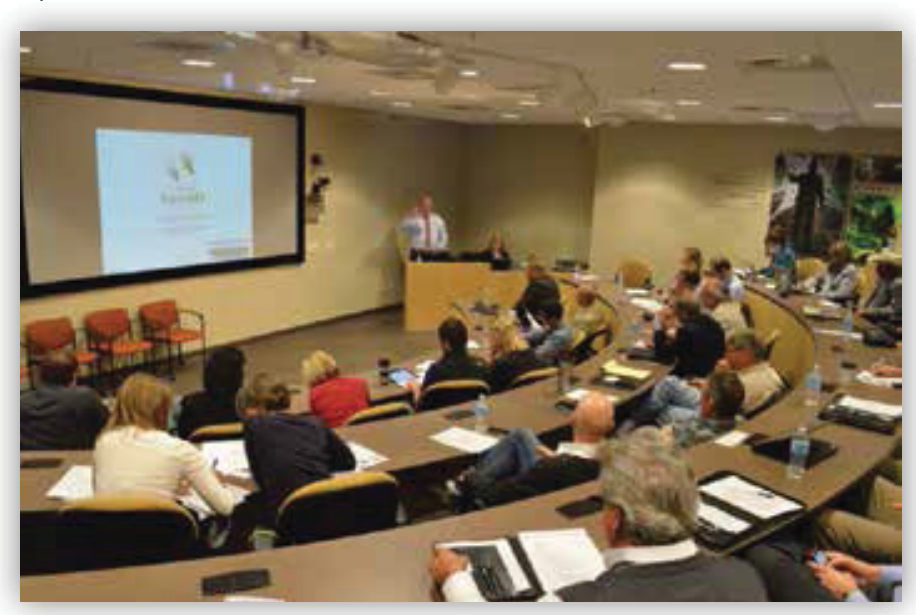

Mike Field, LinkIDAHO's statewide broadband coordinator, shared new ideas to further broadband expansion and adoption throughout the state at a special connectivity conference held at the Center for Advanced Energy Studies.

\section{Regional Partners to Promote Job Growth}

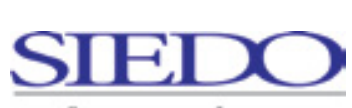

SoUTHER IDAHo

Economic DevelopMENT

ORganization
More than 100 members attended

Southern Idaho Economic Development Organization (SIEDO) Annual Summit in September 2013. INL's TBED forged a partnership twelve years ago with SIEDO, which has attracted more than 30 companies during that time. A vibrant economic engine in the state, SIEDO celebrated five successes this past year, including the one-million-squarefoot Chobani processing plant, Glanbia's new headquarters and innovation center, McCain Foods' expansion, Calva Products' and Monsanto's new Wheat Technology center. TBED through the College of Southern Idaho Foundation, SIEDO and Business Plus donated \$18,500 for economic development activities in southern Idaho during 2013.

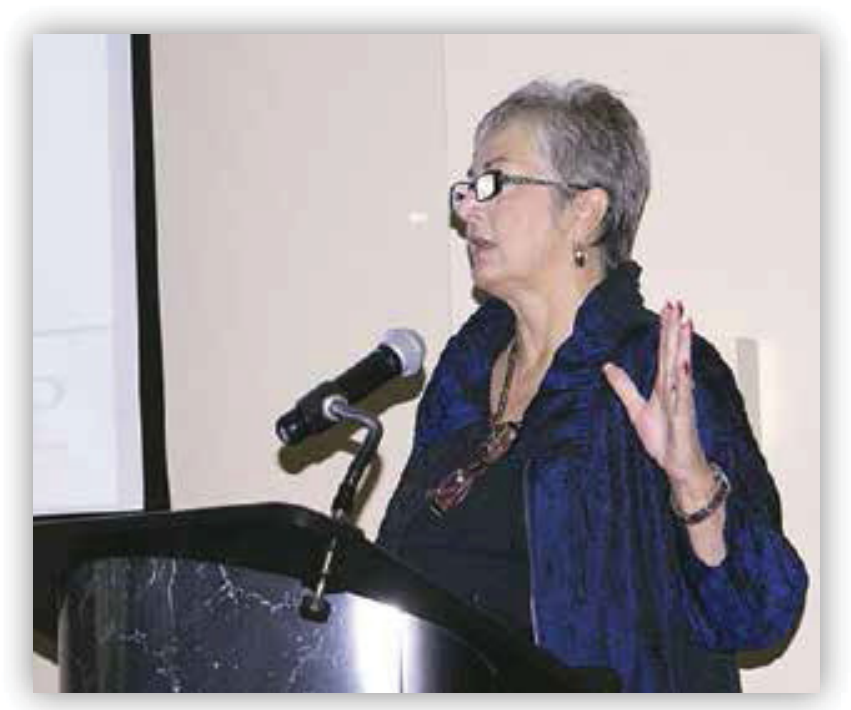

Executive director Jan Rogers addresses SIEDO 


\section{Inspire}

\section{A Brigham Young University- Idaho Student Team}

"School is cake for me," said Christopher Castillo, "but this MorphoHawk project really made me stretch."

Working on their senior capstone project, Castillo and four more Brigham Young University-Idaho students were inspired to research and find companies that may be interested in licensing the technology.

MorphoHawk, developed by INL's Michael Glazoff, is a patent-pending computational method that solves many types of image and signal analysis challenges. Specifically, it extracts useful information from images obtained under changing conditions, such as varied weather or lighting. The technology monitors known objects or terrain to automatically identify the appearance of new objects of interest.

Each year, INL's Technology Deployment partners with regional colleges and universities to launch, develop and sponsor a wide variety of student research activities. Students learn about INL's missions, while conducting research on technology transfer in various marketplaces and gaining technology business experience.

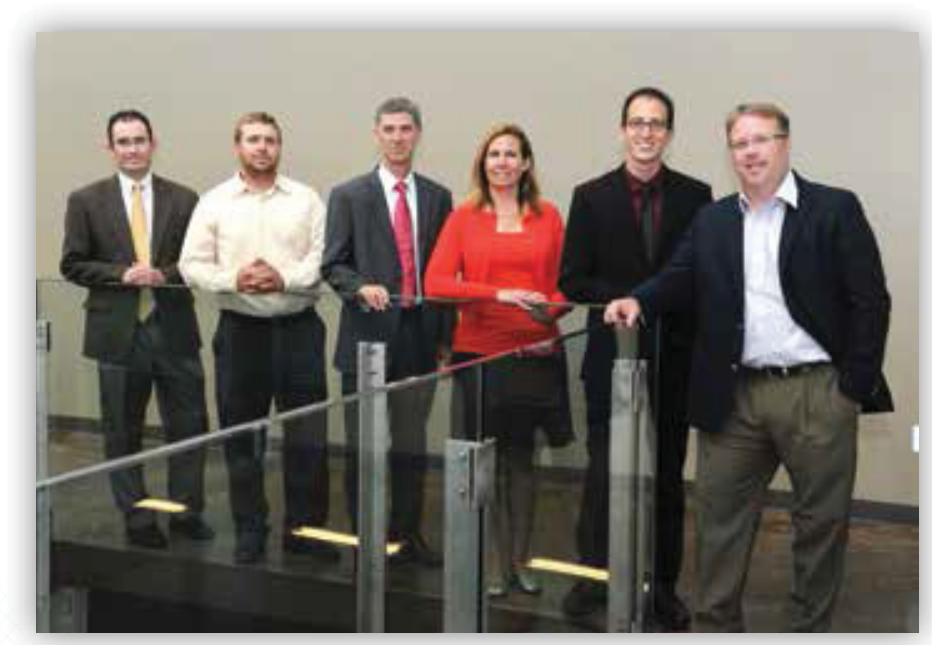

In FY2013, a BYU-Idaho student team did market research on INL's MorphoHawk. Left to right, Taylor Woods, mentor at BYU-Idaho; Ben Goodrich of INL; Jack Fuller, E-Center mentor; Stephanie Cook of INL; Christopher Castillo, BYU-I student; and Jason Stolworthy of INL met to discuss MorphoHawk.

\section{Entrepreneurs}

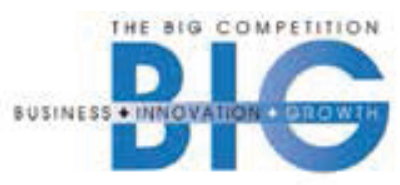

The Business + Innovation + Growth, BIG, Competition was held at the Center for Advanced Energy Studies (CAES) and attracted 50 attendees in March 2013. Six eastern Idaho entrepreneurs presented their "BIG" ideas and commercialization plans to a panel of seven judges. The winner was ReadyLight Pistol Light. Second place and the People's Choice award went to Advanced Ceramic Fibers. Created to aid in the deployment and diffusion of technology, the BIG Competition was sponsored by partnerships among INL's TBED, Eastern Idaho Economic Development Corporation, and Grow Idaho Falls. During 2013, TBED contributed $\$ 11,000$ to Eastern Idaho Economic Development Corporation.

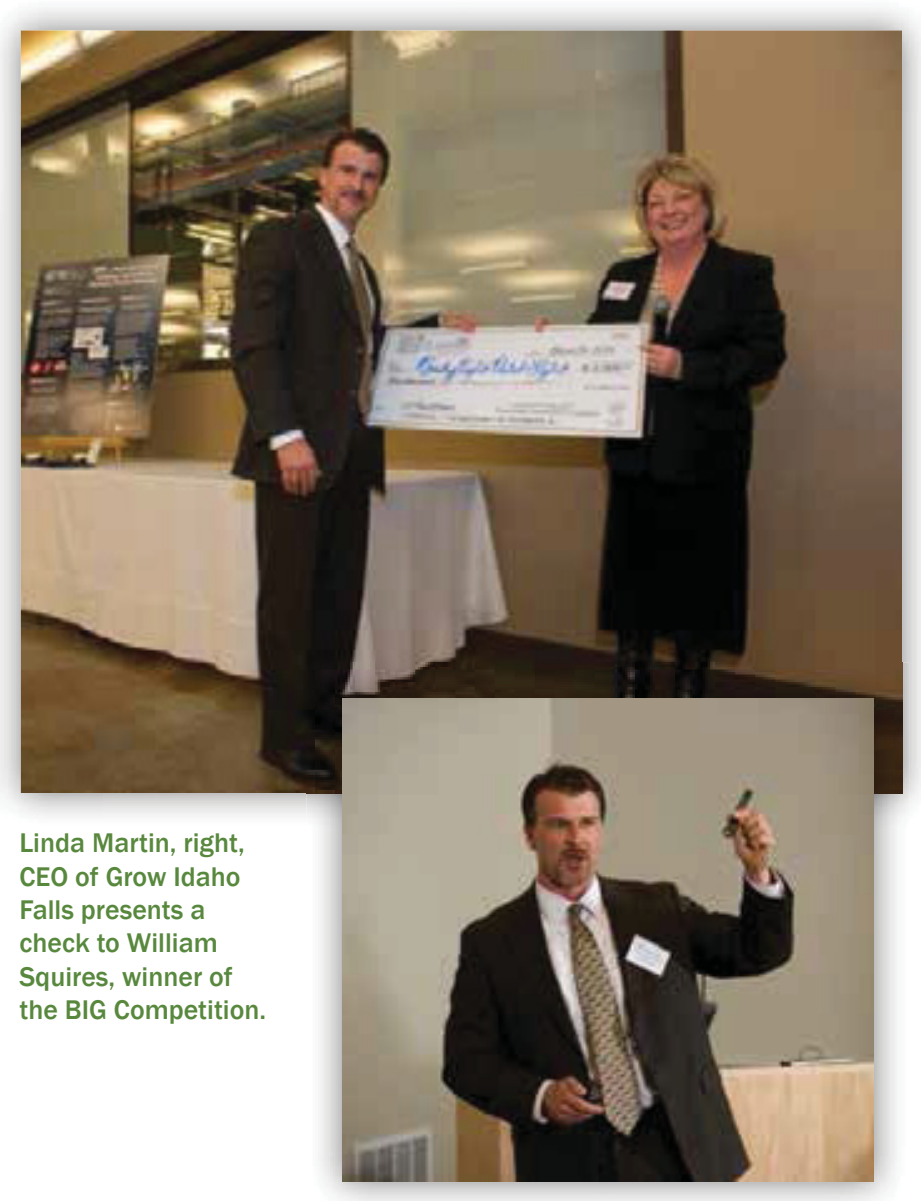

Sergeant William Squires describes the ReadyLight Pistol Light to judges during the competition. 


\section{Innovative and Promising Technology Startups}

In June, TechLaunch 10.0 attracted Idaho's entrepreneurs and early stage companies to compete in a 'startup competition' held in Boise. Chris Walker, a recent University of Idaho graduate, from Element Robot won for his 3D printing, cloud-based software and shared printing hardware. A gold sponsor for
TechLaunch 10.0, INL contributed $\$ 10,000$ to the event. Students from BYU-Idaho, Boise State University and University of Idaho competed in CrowdPitch, an elevator speech competition, which provides an opportunity for individuals to present their ideas to an audience.

Since 2004, 55 of the 72 companies - that is more than 76 percent - participating in TechLaunch are still in business today. Those firms continue to grow and have attracted more than $\$ 40$ million in R\&D and investment capital.

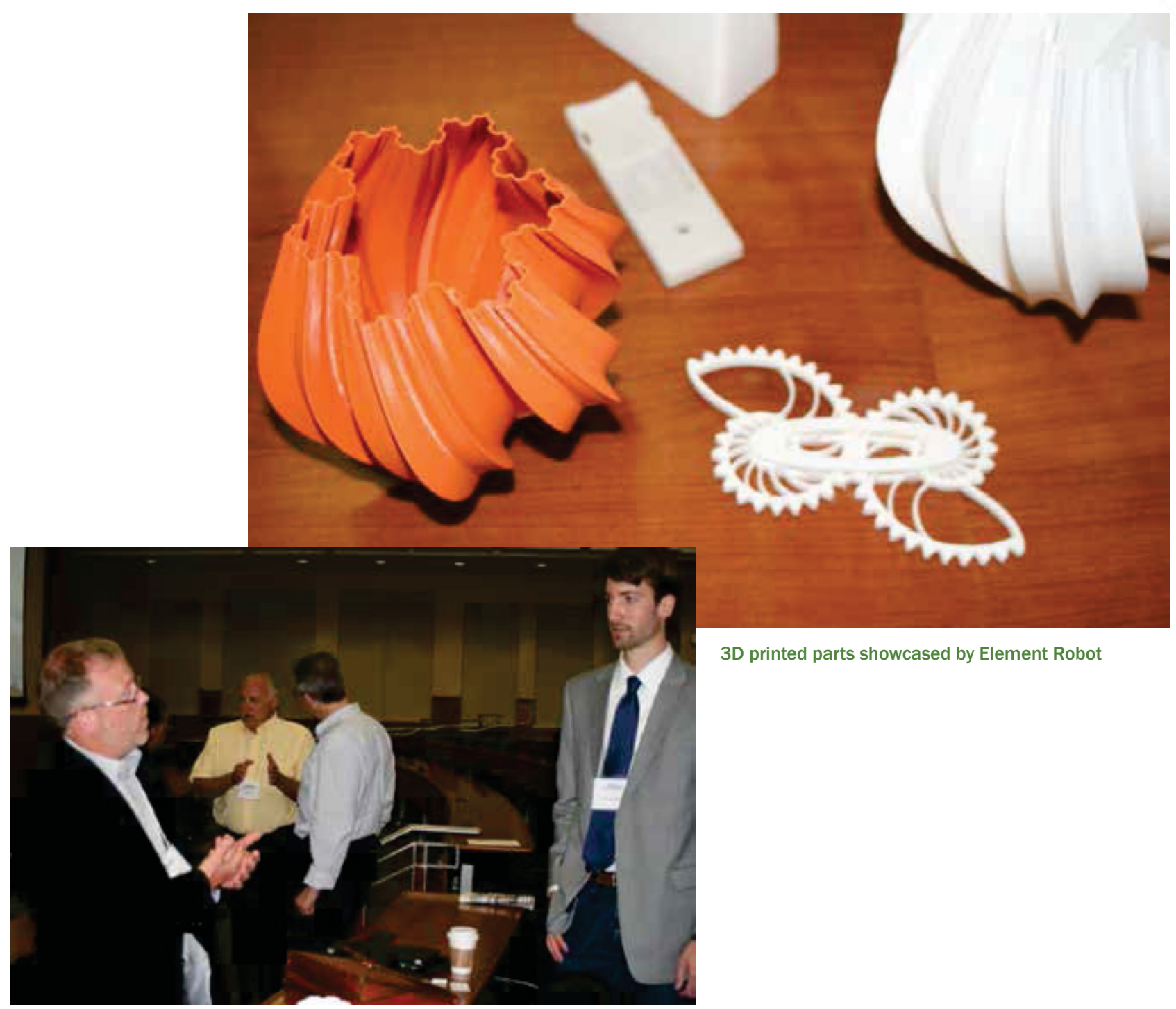

INL deputy director of Technology Deployment Jason Stolworthy, left, and Chris Walker from Element Robot discuss 3D printing technology during TechLaunch 10.0 . 


\section{SPS FO cleanses water,}

\section{wins awards}

\section{By Keith Arterburn}

Accolades and awards just keep coming!

A three-person research team, led by a young researcher who joined INL in 2010, offers a new technology to cleanse industrial waste water, while earning recognition.

Aaron Wilson is a research chemist who joined INL in 2010 and for his first assignment he was asked to conduct a literature search on water technologies in preparation for a conference on water. During his search, he discovered research at Canada's Queens University investigating the use of switchable polarity materials for extracting oils from plants.

Wilson was intrigued with the idea of materials switching polarity in a process and thought it might be application to water processing. Indeed, it was.

Sharing his idea with membrane and process specialists Fred Stewart and Mark Stone, INL managers soon provided some lab-directed funding to adapt the idea. Before long he and his team were filing a new patent for Switchable Polarity Solvents Forward Osmosis (SPS FO).

SPS FO combines the switchable polarity quality with forward osmosis to cleanse industrial waste water. It leverages the switching qualities of selected specialized thermolytic salts (a class of catalysts) and the characteristics of specialized membranes to accomplish the task. Low cost and environmentally friendly, the SPS FO process can purify water from extremely concentrated solutions, especially those containing salts, organics, inorganics, biologics, and many other materials. It has application for reprocessing industrial waste water and desalinating sea water for thirsty nations.
INL nominated SPS FO for the prestigious international 2013 R\&D 100 Award in April and in July it was selected as a winner, INL's 48th award in this competition since 1986.

The team received congratulations from many, including Energy Secretary Ernest Moniz, who said, "The scientists and engineers who developed these award-winning technologies at the cutting edge facilities across our national labs are keeping Americans at the forefront of the innovation community and assuring our nation's economic competitiveness and national security."

In Sept., SPS FO added another trophy to its mantel winning the 2013 Federal Laboratory Consortium, Far West, award as the outstanding technology development. Within a week or so, the team was selected as a finalist in the regional competition for the Idaho Innovation Awards. On Oct. 23, Wilson accepted the trophy for the Early Stage Innovation Award at the Idaho Innovation Award dinner in Boise, which hosted 750 entrepreneurs, investors, educators and technology experts.

Wilson said, "The innovation award is a great honor for our team. At this point I'm looking forward to working with my fellow INL researchers, management, technology deployment, and our collaborators to further develop and deploy the SPS FO water treatment technology."

Several companies are interested in SPS FO and have signed license option agreements for further development, including Chevron's Energy Technology Company. Development continues for the research team and their efforts to develop a low-cost, water purification process will help industry and begin relieving pressure on valuable water sources around the globe.

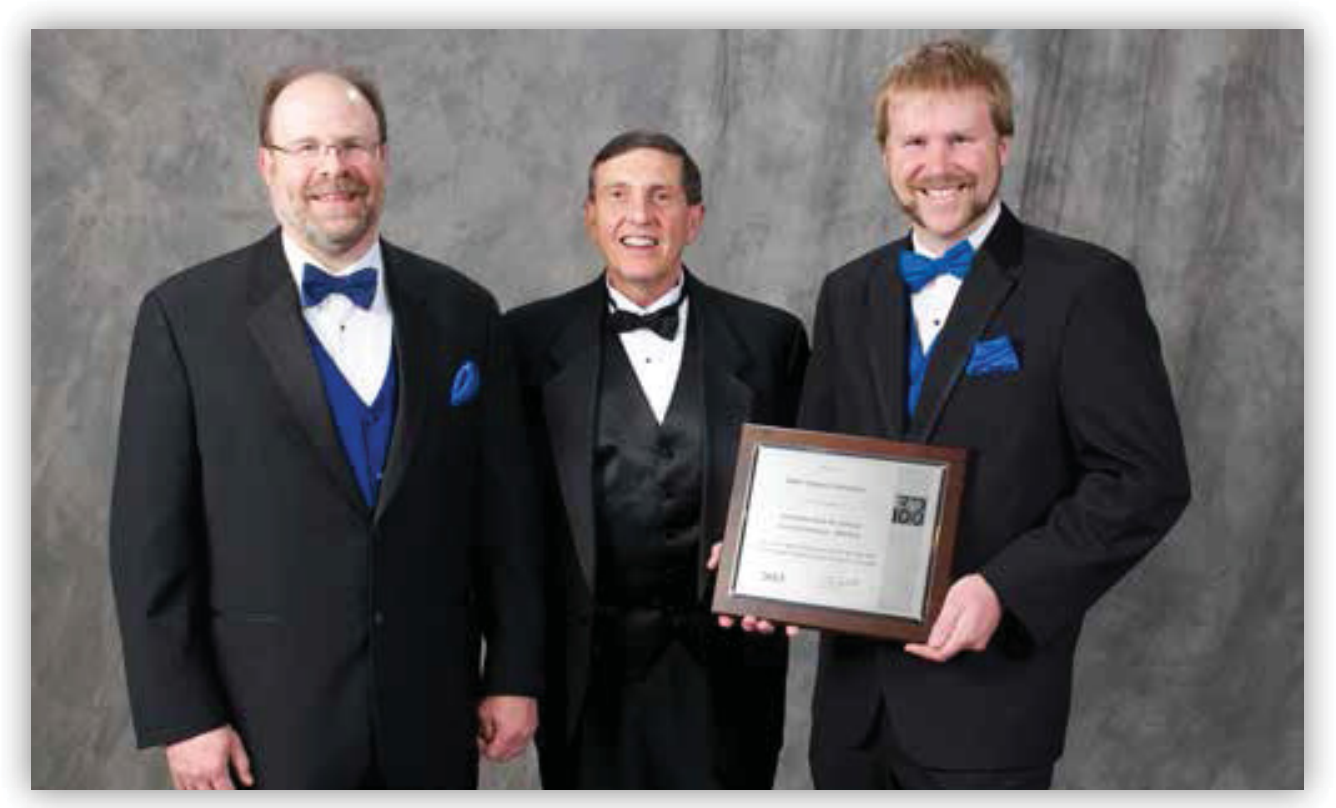

SPS FO team members, Fred Stewart, left, and Aaron Wilson, right, were accompanied to the annual R\&D 100 Award dinner by their manager, Mike Mcllwain, center. 


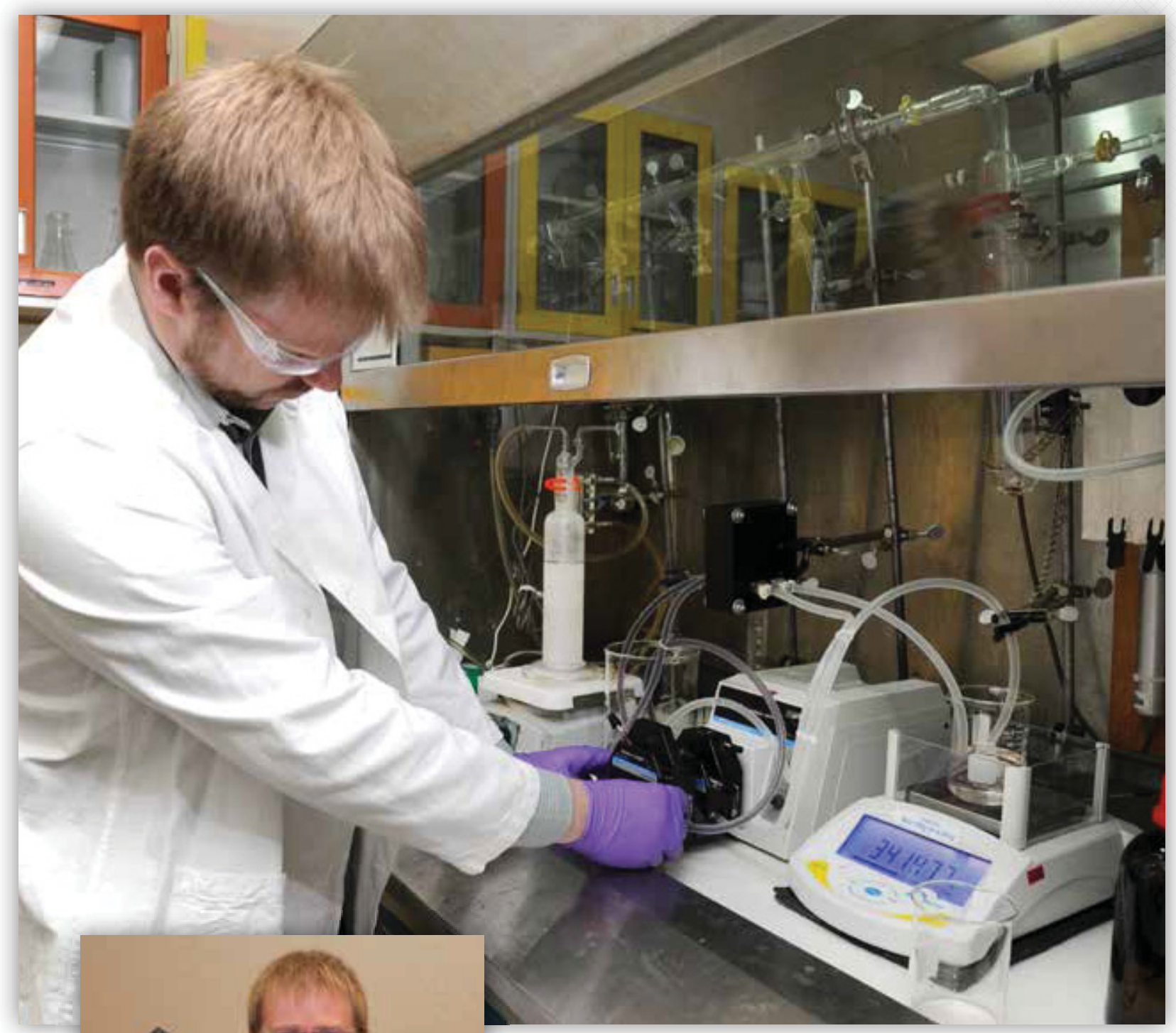

INL principal investigator Aaron Wilson sets up a bench scale test of INL's Switchable Polarity Solvent Forward Osmosis technology.

Aaron Wilson displays the Idaho Innovation Award, which he accepted for the Early Stage Technology category at the award dinner in Boise on Oct. 23, 2013. 
Technology Deployment 
